\title{
The Impact of Non-Saccharomyces Yeast on Traditional Method Sparkling Wine
}

\author{
Nedret Neslihan Ivit ${ }^{1,2}$ and Belinda Kemp ${ }^{3,4, * \text { (iD }}$ \\ 1 Perennia Food and Agriculture Inc., 32 Main Street, Kentville, NS B4N 1J5, Canada; nivit@perennia.ca \\ 2 Office of Industry and Community Engagement, Acadia University, 210 Horton Hall, 18 University Ave, \\ Wolfville, NS B4P 2R6, Canada \\ 3 Cool Climate Oenology and Viticulture Institute (CCOVI), Brock University, 1812 Sir Isaac Brock Way, \\ St. Catharines, ON L2S 3A1, Canada \\ 4 Department of Biological Science, Faculty of Maths and Science, Brock University, 1812 Sir Isaac Brock Way, \\ St. Catharines, ON L2S 3A1, Canada \\ * Correspondence: bkemp@brocku.ca
}

Received: 1 August 2018; Accepted: 23 August 2018; Published: 1 September 2018

\begin{abstract}
The interest in non-Saccharomyces yeast for use in sparkling wine production has increased in recent years. Studies have reported differences in amino acids and ammonia, volatile aroma compounds (VOCs), glycerol, organic acids, proteins and polysaccharides. The aim of this review is to report on our current knowledge concerning the influence of non-Saccharomyces yeast on sparkling wine chemical composition and sensory profiles. Further information regarding the nutritional requirements of each of these yeasts and nutrient supplementation products specifically for non-Saccharomyces yeasts are likely to be produced in the future. Further studies that focus on the long-term aging ability of sparkling wines made from non-Saccharomyces yeast and mixed inoculations including their foam ability and persistence, organic acid levels and mouthfeel properties are recommended as future research topics.
\end{abstract}

Keywords: non-Saccharomyces; yeast; sparkling wine; nitrogen; aroma

\section{Introduction}

One of the main ways to make sparkling wine is the traditional method, also known as Methodé champenoise in Champagne [1,2], and other parts of the world as the classic method, Methode traditionale or bottle-fermented [3]. The traditional method of sparkling wine production differs from other winemaking processes in so much as the second alcoholic fermentation and the aging on yeast lees, both take place in sealed bottles (Figure 1). These are the same bottles that customers purchase from shops and restaurants [4-7]. Sparkling wines produced by the traditional method include Champagne wines in France, Cava in Spain, Brazil, Italy, USA, Australia, New Zealand, England, South Africa and Canada [3,4,6-10].

The first alcoholic fermentation to produce base wine is typically started by yeast inoculation. It occurs at controlled temperatures usually below $20^{\circ} \mathrm{C}[1,11]$. The malolactic fermentation (MLF) of the base wine is optional, depends on the decision of the producer, the malic acid level, intended wine style and the desired flavor profile [1,3]. Each producer aims to bring together the characteristics of different grape varieties, different base wines and different years by blending base wines [12]. At this stage, the wine becomes a "cuvée," which refers to blended base wines, which go on to be fermented in bottles [1]. Wines also undergo tartaric stabilization and filtration to remove prior to bottling [8,11]. 


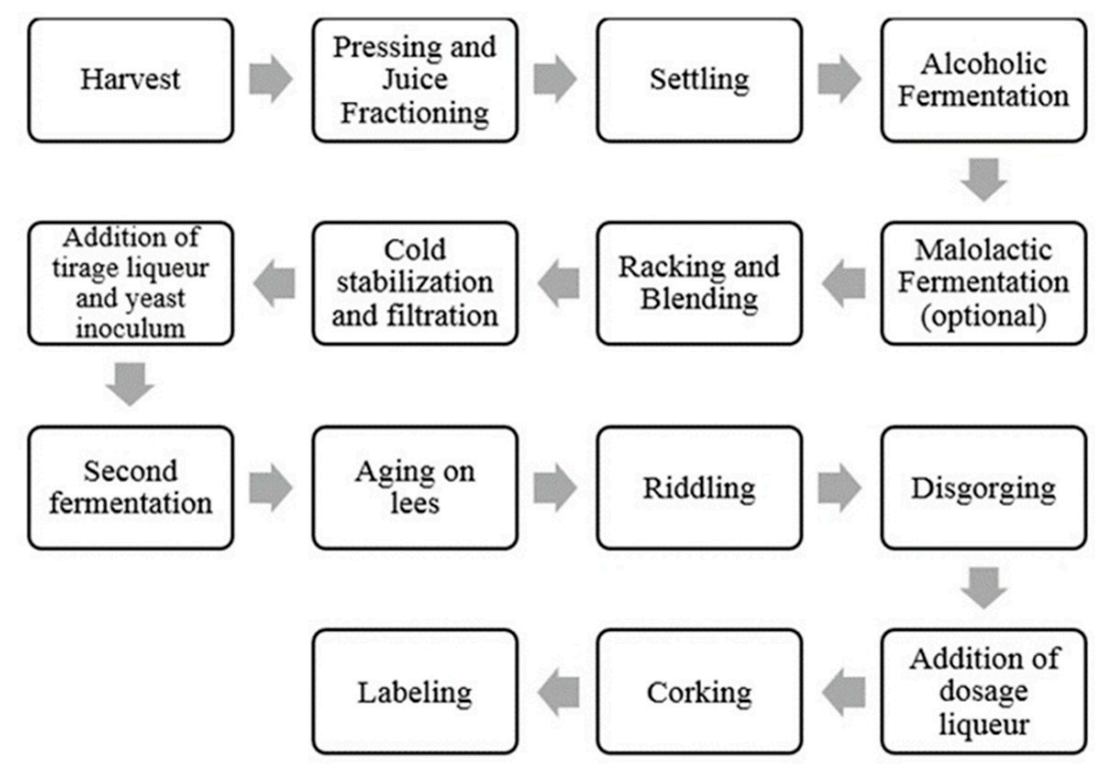

Figure 1. Traditional method sparkling wine flowchart that depicts the steps of production, which described in Section 1 of this review.

Liqueur de tirage is a concentrated sucrose solution that may contain necessary yeast nutrients or adjuvants. The composition of the liqueur de tirage may vary depending on the producer [3]. Generally, $24 \mathrm{~g} / \mathrm{L}$ of sucrose is added to each bottle [1], since $4-4.30 \mathrm{~g}$ of sugar results in one atmosphere (atm) of carbon dioxide $\left(\mathrm{CO}_{2}\right)$. The aim is to reach between 5-6 atm of $\mathrm{CO}_{2}$ by the end of the bottle fermentation [7]. Each bottle is inoculated with an initial yeast population of $1.5 \times 10^{6}$ cells $/ \mathrm{mL}$ [13]. The second fermentation in the bottle, also referred to as "prise de mousse," is followed by aging in contact with the yeast lees at low temperatures, approximately $12-16{ }^{\circ} \mathrm{C}$ [5]. Once the wines are deemed ready, the bottles are riddled to move the yeast cells to the neck of the bottles. The next stage is disgorging, which involves freezing the neck of the bottle in a brine at $-25{ }^{\circ} \mathrm{C}$. The frozen yeast deposit is then eliminated under pressure when the bottle is opened and the dosage, is immediately added then the bottle is the closed with a cork/closure and labelled [14].

\subsection{Non-Saccharomyces Yeasts}

Alcoholic fermentation for winemaking is usually carried out by inoculating the juice Saccharomyces cerevisiae yeast, the most widely used yeast, often referred to as "conventional" wine yeast. Throughout the past decade, "non-conventional" yeasts have become popular [15] and the effects of non-Saccharomyces yeasts on wine quality has been extensively studied [16]. Traditionally, only negative impacts of non-Saccharomyces were investigated, since they were believed to be reason for the microbial-related problems during winemaking. These included a high production of undesirable compounds i.e., acetic acid, ethyl acetate and acetaldehyde [17-19]. It has been suggested that widespread use of commercialized S. cerevisiae strains in winemaking creates uniformity in wines [2]. However, the exclusion of non-Saccharomyces yeasts from the fermentation process may result in a loss of complexity and result in wines lacking distinctive character [20,21]. Non-Saccharomyces yeasts, which are naturally found on grapes may positively affect wine quality [22]. Spontaneous wine fermentations initially start with indigenous yeasts, the native microbiota of the grape juice but Saccharomyces cerevisiae will, in most cases, take over and complete the fermentation [23]. Researchers have highlighted the positive role of non-Saccharomyces yeast, as well as their negative role on the chemical composition and sensory profile of resultant wines $[19,24,25]$. The increased knowledge of yeast biochemistry and physiology has made the selection of yeast strains with specific traits possible [21]. The potential benefits for using non-Saccharomyces yeast in winemaking has been 
well documented for still wines but far less so for sparkling wines [18]. The current demand for innovative wines in the competitive international market creates new opportunities to make wines with unique characteristics [26,27]. This increased knowledge combined with the interest from the wine market has produced commercially available non-Saccharomyces yeasts in the form of both dry active and frozen yeasts, i.e., Torulaspora delbrueckii, Metschnikowia pulcherrima and Pichia kluyveri $[18,22]$. The main oenological properties of non-Saccharomyces yeasts have been reviewed [28], as well as the technological and safety issues that these yeasts can solve, such as volatile acidity, alcohol reduction, high glycerol content, enhanced varietal aromas and the reduction of contaminants [28]. The current purpose of using non-Saccharomyces yeasts in winemaking varies. It is possible to use non-Saccharomyces as a sole yeast, although most studies demonstrate that sequential inoculation, or co-inoculation with mixed starter cultures of a non-Saccharomyces with a S. cerevisiae are preferred [29]. Recently, Comitini et al. [27] reviewed the specific purposes and benefits of non-Saccharomyces species in winemaking, which included the improvement of the complexity of the aromatic profile of wines, control of undesirable microflora, alcohol reduction and low sulfur dioxide $\left(\mathrm{SO}_{2}\right)$, hydrogen sulfide $\left(\mathrm{H}_{2} \mathrm{~S}\right)$ and acetaldehyde concentrations, along with the reduction in copper. The main non-Saccharomyces species found in vineyards and wineries include Aureobasidium, Brettanomyces, Debaryomyces, Hanseniaspora, Metschnikowia, Lachancea, Torulaspora, Pichia, Rhodotorula, Starmerella and Zygosaccharomyces, which were recently reviewed by Varela and Borneman [30]. Further studies have investigated specific effects of non-Saccharomyces yeast on wine quality. The yeasts that were studied include Hanseniaspora uvarum [31,32], Hanseniaspora vineae [26,33], Torulaspora delbrueckii [34-38], M. pulcherrima [29,39-41], Starmerella bacillaris [22,42], Schizosaccharomyces pombe [43,44], Schizosaccharomyces japonicus [16], Lachancea thermotolerans [29,40,45], Zygotorulaspora florentina [46], P. kluvyeri [22,47], and Zygosaccharomyces bailii [48,49].

T. delbrueckii, was one of the first commercial non-Saccharomyces yeast on the market [18]. T. delbrueckii produces low concentrations of glycerol, acetaldehyde, acetic acid and ethyl acetate. In the mixed or sequential fermentation with S. cerevisiae, it has improved faults particularly volatile acidity [50]. Studies that used it for first fermentations found that it increased glycerol concentration compared to other yeasts in the trial, decreased volatile acidity and had positive effects on foaming properties [35]. It has also been utilized for second fermentation in bottle both in solitary and mixed fermentation, and found suitable for sparkling wines. However, the wines produced had a different aroma composition and sensory profile compared to those of the $S$. cerevisiae strains [51].

M. pulcherrima is a high producer of $\beta$-glucosidase and its presence in mixed cultures can decrease volatile acidity, yet increase the production of medium-chain fatty acids (MCFA), alcohol, esters, terpenols and glycerol. Its contribution to base wine aroma profiles and improved foaming characteristics has been established [35].

Schizosaccharomyces pombe species is extremely useful in cold viticultural regions due its ability to transform malic acid into ethanol [50]. This ability makes it possible to significantly reduce of the levels of biogenic amines and ethyl carbamate precursors without the need for any MLF [44]. It is able to ferment sparkling base wine to dryness without producing any aromatic defects [52].

L. thermotolerans enhances wine acidity and increases the overall perceived wine quality [53]. Its' ability to produce L-lactic acid from glucose and fructose could be used to increase acidity in sparkling wines produced in warm viticultural regions [54].

As the characteristics of yeast species differ, the importance of strain/isolate differences must be considered. The effect of yeast strain differences on the chemical composition of sparkling wines, as well as on still wines, has been studied. Martínez-Rodríguez et al. [55] showed the different influence of five yeast strains of the species S. cerevisiae and S. bayanus on the content of free amino acids and peptides during ageing in contact with yeast lees, for traditional method sparkling wines [55]. Perpetuini et al. [56] studied 28 strains of S. cerevisiae that had different flocculation abilities. These authors showed that using new starting strains to improve sparkling wine was possible. Another study investigated six strains of S. cerevisiae and reported phenotypic differences in the concentration 
of aroma compounds of the finished sparkling wines [57]. These studies illustrate the importance of yeast species and strain selection, on the final attributes of sparkling wines.

\subsection{Non-Saccharomyces Yeasts and Sparkling Wine}

The fermentation media for the second fermentation for traditional method wines creates a hostile and unfavorable environment for yeast $[57,58]$. These conditions include high ethanol content $(10-12 \%$ $v / v)$, low $\mathrm{pH}(2.9-3.2)$, low temperatures $\left(10-15^{\circ} \mathrm{C}\right), \mathrm{SO}_{2}$ concentrations (50-80 mg/L) high total acidity $\left(5-7 \mathrm{~g} / \mathrm{L} \mathrm{H}_{2} \mathrm{SO}_{4}\right)$, nitrogen starvation and $\mathrm{CO}_{2}$ pressure $[58,59]$. Their ability to re-ferment base wines to produce sparkling wines is crucial but also critical for post fermentation, since the second alcoholic fermentation is followed by a period of aging on yeast lees $[2,60]$. Several characteristics are taken into account when choosing yeast for the second fermentation, amongst them are their resistance to high pressure (5-6 atmosphere), resistance to ethanol and the ability to ferment at low temperatures [11]. It can also increase the quality of the product due to its autolytic ability, good flocculation ability (to facilitate lees movement during riddling) and organoleptic properties [61].

The interest in non-Saccharomyces yeast for use in sparkling wine production has increased in recent years, and hence generated a new research area for wine scientists (Table 1). To the best of our knowledge, the focus of the studies on non-Saccharomyces yeasts, for traditional method sparkling wine, include: T. delbrueckii, M. pulcherrima, S. pombe and Saccharomycodes ludwigii. Differences in amino acids, ammonia, volatile aroma compounds (VOCs), glycerol and proteins, which impact sparkling wine flavor and foaming ability, have been reported (Table 1). Due to a lack of research specific to sparkling wines, studies concerning the influence of non-Saccharomyces yeast on still wines have been used in the following section to predict the possible effects on sparkling wines. Nitrogenous compounds with a focus on amino acids, ammonia, biogenic amines and VOCs, proteins, organic acids and sensory qualities have been considered. Despite the substantial potential of non-Saccharomyces for sparkling wine production, further investigation is required to understand the possible effects of non-Saccharomyces for second fermentation and aging [60]. Therefore, the following section of this review discusses our current knowledge concerning the impact of non-Saccharomyces yeasts on traditional method sparkling wine. 
Table 1. Effects of non-Saccharomyces yeasts studied in base wines and sparkling wines.

\begin{tabular}{|c|c|c|c|c|c|c|}
\hline Yeast Name & Production Stage & Isolation Method & Grape Variety Used & Studied Parameters & Effect on Sparkling Wine & Reference \\
\hline T. delbrueckii & Second fermentation & $\begin{array}{l}\text { Originally isolated from } \\
\text { natural matrices from } \\
\text { different environments. }\end{array}$ & $\begin{array}{l}\text { White base wine made of } \\
\text { Verdicchio from Ancona, Italy. }\end{array}$ & $\begin{array}{l}\text { Ethanol, volatile acidity, } \\
\text { sensory analysis and VOCs. }\end{array}$ & $\begin{array}{l}\text { Positive, distinctive effects on } \\
\text { overall aroma and sensory } \\
\text { characteristics of wines } \\
\text { were reported. }\end{array}$ & [51] \\
\hline S. pombe & Second fermentation & $\begin{array}{l}\text { Previously isolated yeasts } \\
\text { from the archive of } \\
\text { Chemistry and Food } \\
\text { Technology Department of } \\
\text { Universidad Politecnica } \\
\text { de Madrid. }\end{array}$ & $\begin{array}{l}\text { White base wine made of Airen } \\
\text { grapes and red base wine made } \\
\text { of Tempranillo grapes, Spain. }\end{array}$ & $\begin{array}{c}\text { Alcohol, total acidity, pH, } \\
\text { sugars, organic acids, glycerol, } \\
\text { anthocyanins, VOCs, amino } \\
\text { acids, biogenic amines, } \\
\text { sensory analysis. }\end{array}$ & $\begin{array}{l}\text { Changes on color, acidity, } \\
\text { volatile compounds, biogenic } \\
\text { amines of the final products as } \\
\text { well as on the sensorial } \\
\text { evaluation was observed. }\end{array}$ & [52] \\
\hline $\begin{array}{l}\text { T. delbrueckii (sequential } \\
\text { inoculation with } \\
\text { S. cerevisiae) }\end{array}$ & $\begin{array}{l}\text { First fermentation } \\
\text { followed by a second } \\
\text { fermentation }\end{array}$ & $\begin{array}{c}\text { Base wine from the } \\
\text { study done by } \\
\text { González-Royo et al. [35] } \\
\text { fermented with S. cerevisiae } \\
\text { bayanus (EC1118 Lallemand } \\
\text { Inc., Montreal, QC, Canada) }\end{array}$ & V. vinifera cv. Macabeo. & $\begin{array}{l}\text { Proteins, polysaccharides and } \\
\text { foaming properties. }\end{array}$ & $\begin{array}{l}\text { Better foaming properties } \\
\text { were observed. }\end{array}$ & [36] \\
\hline $\begin{array}{l}\text { T. delbrueckii (sequential } \\
\text { inoculation with } \\
\text { S. cerevisiae) }\end{array}$ & \multirow{2}{*}{ First fermentation } & \multirow{2}{*}{$\begin{array}{l}\text { Commercial yeasts of } \\
\text { T. delbrueckii (Biodiva }{ }^{\mathrm{TM}} \text { ) and } \\
\text { M. pulcherrima }\left(\text { Flavia }^{\circledR}\right) \text { from } \\
\text { Lallemand Inc., Montreal, } \\
\text { QC, Canada. }\end{array}$} & \multirow{2}{*}{ V. vinifera cv. Macabeo. } & \multirow{2}{*}{$\begin{array}{l}\text { Ethanol, titratable acidity, } \mathrm{pH}, \\
\text { volatile acidity, glycerol, } \\
\text { proteins, foaming properties, } \\
\text { polysaccharides, VOCs, } \\
\text { sensory analysis. }\end{array}$} & \multirow{2}{*}{$\begin{array}{l}\text { Base wines with different } \\
\text { characteristics were obtained. } \\
\text { Positive effects on foaming } \\
\text { properties were observed. }\end{array}$} & \multirow{2}{*}{ [35] } \\
\hline $\begin{array}{c}\text { M. pulcherrima } \\
\text { (sequential inoculation of } \\
\text { S. cerevisiae) }\end{array}$ & & & & & & \\
\hline
\end{tabular}




\section{Nitrogenous Compounds and Non-Saccharomyces Yeast}

Grapes and wine contain many nitrogenous compounds in both inorganic forms (ammonia and nitrate) and organic forms (amines, amides, amino acids, pyrazines, nitrogen bases, pyrimidins, proteins and nucleic acids) [62]. For sparkling wines, the nitrogen fraction consists mostly of peptides, free amino acids and proteins. Different aspects of sparkling wines are influenced by juice and base wine nitrogen composition including foam quality, aroma profile and organoleptic characteristics $[6,63]$. Nitrogen compounds, mainly peptides and amino acids are considered the major compounds that are released into wine during yeast autolysis $[55,64,65]$.

The interactions between base wine, temperature and yeast strain have the strongest effect on fermentation kinetics $[66,67]$. During second fermentation in bottle, the wines are kept at a relatively stable temperature, preferably between $10{ }^{\circ} \mathrm{C}$ and $15{ }^{\circ} \mathrm{C}$ [1]. The beginning of yeast autolysis may differ by up to several months depending on the storage conditions. Although there is no agreement about the time needed for yeast autolysis [68], it has been reported that it commences after 2-4 months after the second fermentation finishes $[5,64,69]$.

\subsection{Yeast Acclimation and Nitrogen Requirements}

The stressful environment for yeast growth the acclimatization of yeast to the base wine is crucial. For this reason, yeasts are cultured in media that contains increasing ethanol concentrations [66,70]. Total assimilable nitrogen (YAN mg N/L) includes all nitrogen sources (amino acids, ammonia and peptides up to five amino acids in length) that can be assimilated and metabolized by yeasts [62]. The YAN content of grape must and its' usage by yeast during the first fermentation will affect the YAN concentration of the base wine. The nitrogen content of the base wines is highly variable (17-75 mg/L). Nevertheless, nitrogen requirements for the second fermentation are very low [66]. During the second fermentation in bottle, the YAN content decreases halfway through due to the yeast consumption in the early stages of the fermentation but increases at the end of the fermentation. This is due to the physiological responses of the yeast to the lack of nutrition, which they restore by means of passive release of nitrogen compounds [64,71].

Liqueur de Tirage ingredients vary depending on the producer and there are different adjuvants listed in literature. Thiamine and nitrogen, usually diammonium phosphate (DAP), at rates of $0.5-100 \mathrm{mg} / \mathrm{L}$ respectively were to base wine. Martí-Raga et al. [66] reported that the addition of nitrogen before fermentation effects fermentation kinetics. However, this is only when the levels of nitrogen are below $30 \mathrm{mg} \mathrm{N} / \mathrm{L}$. Nitrogen addition in the yeast acclimation media had a strong impact on yeast growth and significantly affected second fermentation kinetics [72]. The effects of non-Saccharomyces yeasts on amino acids and ammonia, biogenic amines and VOCs in sparkling wines are discussed in the following sections.

\subsection{Amino Acids and Ammonia}

Amino acids improve the aroma potential of sparkling wines since they are the precursors of several aroma compounds produced from deamination or decarboxylation reactions [73]. Ammonia is the nitrogen form most directly assimilable by yeasts [74] and $\mathrm{NH}_{4}{ }^{+}$ammonium cation is the form most directly assimilable by yeasts. Amino acids such as $\alpha$-alanine, serine, arginine, proline, glutamic acid and its amide form, glutamine, known to be an ammonia transporter are some of the amino acids that are predominant in must. Concentration of arginine and proline depends on the grape variety, although during fermentation most $S$. cerevisiae yeasts and lactic bacteria use arginine [74]. Moreno-Arribas et al. [68] studied the amino acid composition of peptides present in sparkling wines. They reported that threonine and serine are a major presence but these were not found in the base wines. Glutamic acid, glutamine and arginine are among the assimilable nitrogen that are the specific nutrients for alcoholic fermentation and microbial metabolism. Amino acids such as leucine, isoleucine, 
threonine, valine and phenylalanine are directly involved in the production of higher alcohols, which have an effect on organoleptic properties [75].

The yeast species and strain influences the content of free amino acids and peptides during ageing in contact with lees $[55,71,76,77]$. When yeasts perform the second fermentation, amino acids and proteins decrease while the peptides are liberated. Next, while nitrogen compounds are used as nutrients for viable cells, proteins are degraded to peptides and converted to amino acids. Finally, when there are no viable cells left, the release of proteins and peptides prevail. After 270 days of aging with yeast lees, the amino acid content of some wines decreases [55]. The changes observed in the amino acid content of wines may be the result of the assimilation and excretion process by yeast during fermentation [78], as well as the adsorption of amino acids by bentonite (if used as an adjuvant). Although, Martínez-Rodríguez and Polo [63] reported that the use of bentonite as a co-adjuvant in the concentrations used $(3 \mathrm{~g} / \mathrm{hL})$ did not affect the amino acid concentration in the sparkling wines.

Gobert et al. [67] investigated the ability of non-Saccharomyces yeasts to consume nitrogen. Sequential fermentation using non-Saccharomyces yeasts (Starmerella bacillaris, M. pulcherrima and Pichia membranifaciens) in grape juice was undertaken and specific amino-acid consumption profiles of non-Saccharomyces yeasts were revealed. Cysteine was found to be the preferred nitrogen source for all non-Saccharomyces yeasts. Histidine, methionine, threonine and tyrosine were not consumed by S. bacillaris, aspartic acid was consumed very slowly by M. pulcherrima and glutamine was not utilized by P. membranifaciens.

These results suggest that a specific addition of amino acids in must should be considered for non-Saccharomyces yeast. Hence specific nitrogen products for non-Saccharomyces fermentations is likely in the future. In the context of indigenous fermentations, the study indicated that non-Saccharomyces yeasts compete with Saccharomyces for nitrogen sources. In contrast, Llexià et al. [79] found that nitrogen limitation increased the time of the fermentation as well as the proportion of non-Saccharomyces yeast at the mid and final stages of fermentation. The authors suggested that under conditions where nitrogen limitation occurs, S. cerevisiae should be co-inoculated to ensure nitrogen availability for this yeast.

Ivit et al. [52] used S. ludwigii (979) and S. pombe (938) for second fermentation of sparkling wines and compared them to S. cerevisiae (7VA) fermentations. Both base wines were produced from Vitis vinifera $\mathrm{cv}$. Airen and V. vinifera cv. Tempranillo grapes, fermented in bottle and aged on lees for four months. The amino acid content of the base wines changed during the second fermentation and some amino acids decreased and others increased. Although no significant change was seen between the base wines and sparkling wines produced with S. cerevisiae, the total amino acids increased for the sparkling wines produced by non-Saccharomyces yeast. This difference in amino acid content between the yeasts could be due to their different release mechanisms, their different amino acid consumption during fermentation and/or the structural composition of the yeasts $[67,80]$.

\subsection{Biogenic Amines}

Biogenic amines (BAs) are a class of nitrogenous compounds in wine that have oenological importance due to their adverse effect on human health and negative impact on wine quality [81-85]. Raw material and fermentation processes are the two sources of BAs in wine [86]. The main BAs found in wine are histamine, tyramine and cadaverine and those reported in grape must include putrescine, ethylamine, 2-phenylethylamine, spermine and spermidine [87]. The three main BAs associated with MLF are histamine, tyramine and putrescine, which are formed mainly by lactic acid bacteria by the decarboxylation of free amino acids [88]. Some authors suggest that certain yeast strains (S. cerevisiae, Brettanomyces bruxellens, Kloeckera apiculata, Candida stellate and M. pulcherrima) can produce BAs in wine $[89,90]$. BAs are also important in wine from an economical point of view, since they may cause problems for import and export processes due to official legal limits in some countries [81]. In many countries, no official maximum limits exist for histamine content in wines, though many wine importers require wines to be analyzed for histamine levels. The current limits are $2 \mathrm{mg} / \mathrm{L}$ in Germany, $4 \mathrm{mg} / \mathrm{L}$ in Holland, $6 \mathrm{mg} / \mathrm{L}$ in Belgium, $8 \mathrm{mg} / \mathrm{L}$ in France and $10 \mathrm{mg} / \mathrm{L}$ in 
Switzerland [91,92]. In sparkling wines, histamine levels of twenty-six Austrian wines were found to be in the range of $0.001-1.9 \mathrm{mg} / \mathrm{L}$ (mean $0.30 \pm 0.55$, median 0.02 ) without significant differences between grape varieties [93]. Konakovsky et al. [94] reported the same range when twenty-nine German, Spanish and Italian sparkling wines were analyzed. Additionally, Caruso et al. [90] studied the effect of non-Saccharomyces yeasts on BAs and their precursors. These authors compared the formation of BAs from different yeast species and strains. B. bruxellensis formed the highest amount of total BAs (average of $15 \mathrm{mg} / \mathrm{L}$ ), followed by S. cerevisiae (average of $12.1 \mathrm{mg} / \mathrm{L}$ ). The other yeast species included K. apiculata and M. pulcherrima formed less than $10 \mathrm{mg} / \mathrm{L}$ of BAs. S. pombe is of particular interest as it reduced the risk of BA formation. Malic acid consumption by $S$. pombe yeast enables a non-bacterial biological de-acidification, which reduces the possibility of lactic acid bacteria growing; thereby reducing the risk of biogenic amine formation [44]. Wines made from Chardonnay grapes, produced with $H$. vineae and S. cerevisiae have both shown reduced BA content [33].

While some of the processes during traditional method sparkling wine production can increase the BA content, others can decrease it. The base wines that are subjected to MLF have more risk of high BA content, since BA concentration increases due to lactic acid bacteria [95]. The amount of BAs increases during contact with yeast lees [81]. The addition of clarification substances and oenological adjuvants such as bentonite or polyvinylpolypirrolidone (PVPP), have been found to reduce BA content, due to their ability to absorb them [96]. Ivit et al. [52] compared two non-Saccharomyces yeasts to one another. In white sparkling wines, total BA concentrations were significantly lower in comparison to the base wine. However, the red sparkling wines produced from S. pombe showed significantly lower total BAs in comparison to wines fermented with S. cerevisiae. This was likely due to different adsorption characteristics from different type of yeast lees during the aging process, or during the fermentation [89].

\subsection{Volatile Aroma Compounds}

Volatile aroma compounds (VOCs) produced by non-Saccharomyces yeasts can be grouped into higher alcohols, esters, aldehydes, volatile fatty acids, volatile phenols and sulfur compounds [24]. Higher alcohols, mainly 3-methyl butanol, 2-methyl propanol and 1-propanol among many others, can contribute aromatic complexity to wine at concentrations below $300 \mathrm{mg} / \mathrm{L}$. However, it can cause a negative effect when the concentration is higher than $400 \mathrm{mg} / \mathrm{L}$ [97]. 2-phenylethyl alcohol has been attributed to floral and rose aromas and isoamyl alcohol with marzipan aromas [75]. Esters are produced by yeasts during fermentation and contribute positively to wine aroma by bestowing fruit characteristics to wine. The main ester in wine, ethyl acetate, causes spoilage at levels of 150-200 mg/L. There are esters that produce pleasant aromas including isoamyl acetate with banana and pear odors, 2-phenethyl acetate with rose, honey, fruity and flowery odors, ethyl hexanoate with apple and violet, and ethyl octanoate with pineapple and pear [75]. Aldehydes, mainly acetaldehyde contributes apple-like odors to wine, and at high levels can also cause spoilage. With regards to carbonyl compounds, diacetyl, is produced by yeast metabolism and the resultant buttery aromas are perceptible at concentrations between at 1-4 $\mathrm{mg} / \mathrm{L} \mathrm{[75].}$

Non-Saccharomyces yeasts can influence the primary and the secondary aromas by the production of enzymes and metabolites, respectively. They have been described in literature as producers of enzymes involved in the release of primary aroma compounds from grape precursors [24]. Secondary aromas formed during fermentation by non-Saccharomyces yeasts include higher alcohols, esters, aldehydes (acetaldehyde), volatile phenols and sulfur compounds [24]. However, non-Saccharomyces yeasts also effect VOCs during aging in contact with yeast lees since yeast autolysis leads to significant changes in wine aroma composition [64]. During their autolysis, yeasts lead to the formation, or degradation of VOCs, which modifies the aroma profile of sparkling wines.

The possibility of modifying wine sensory profile by using combinations of non-Saccharomyces yeasts with Saccharomyces yeast strains has been studied extensively [37,98,99]. Englezos et al. [42] studied the effect of mixed fermentations of Starmerella bacillaris (synonym Candida zemplinina) 
with S. cerevisiae on the aroma profile and composition of Barbera wines. The wines produced from mixed cultures contained higher amounts of pleasant esters compared to the wine fermented with S. cerevisiae alone. Lencioni et al. [46] compared mixed fermentation of Z. florentina with S. cerevisiae to a fermentation with only $S$. cerevisiae and showed that the mixed fermentation produced a higher concentration of 2-phenylethanol. Furthermore, Belda et al. [37] reported that T. delbrueckii, used for white wine fermentation, increased the concentration of volatile thiols, with 4-methyl-4-sulfanylpentan-2-one (4-MSP) found over its sensory threshold level. Reduced alcohol wines fermented with M. pulcherrima and S. uvarum were described as having red fruit and berry aromas [39]. M. pulcherrima wines had higher concentrations of ethyl acetate, total esters and total higher alcohols [39]. The effect of $H$. uvarum in mixed fermentations with $S$. cerevisiae found that simultaneous fermentations and extracellular extract of $H$. uvarum, improved the overall quality of wine aromas, by increasing fruity and floral traits and enhancing terpenes, C13-norisoprenoids, acetate esters, ethyl esters and fatty acids [32]. Romani et al. [16] studied the effect of S. japonicus and found that the sequential fermentation with $S$. cerevisiae enhanced wine complexity and aroma by increasing higher alcohols (isobutanol, amylic and isoamylic alcohols), acetate esters (isoamyl acetate, phenyl ethyl acetate) and alcohols ( $\beta$-phenyl ethanol) above their threshold levels. The effect of co-inoculation of T. delbrueckii and S. cerevisiae on Moscato Branco sparkling wines found that wines produced from co-fermentation had higher concentrations of 2-phenyl ethanol, acetate and ethyl esters with fruity and flowery descriptors while a decrease in concentration of undesirable compounds such as volatile fatty acids occurred [38].

Escribano et al. [49] determined the fermentation behavior and aroma formation from several non-Saccharomyces yeasts. Twenty-five yeasts from nine species were studied (Candida zeylanoides, Cryptococcus uzbekistanensis, Debaryomyces hansenii, L. thermotolerans, M. pulcherrima, T. delbrueckii, Williopsis pratensis, Zygosaccharomyces bailii and S. cerevisiae) in pasteurized grape juice. These authors suggested that M. pulcherrima was a good candidate for wine fermentation due to the formation of high concentrations of 2-phenyl ethyl alcohol and 2-phenyl acetate in the resultant wine. They further demonstrated the possibility of using M. pulcherrima and L. thermotolerans as an inoculum. First and second fermentations significantly alter the volatile composition of sparkling wines and aroma profile $[5,6,100]$. Some VOCs (i.e., esters, aldehydes and terpenes) can be adsorbed onto yeast lees, reducing their concentration in aged sparkling wines, although this depends on the structure of the yeast cell walls [101].

Yeast undergo important changes during second fermentation in sealed bottles under $\mathrm{CO}_{2}$ pressure, before aging with yeast lees [5]. Different native yeast strains have been used for in-bottle fermentation to overcome uniformity in sparkling wine [2]. The study stated that an increase in the choice of available yeast strains for second fermentation in bottle would be useful for the differentiation of sparkling wines. Even so, few studies exist on the effect of non-Saccharomyces yeasts on VOCs in base wines and sparkling wines. Chardonnay and Pinot noir musts were fermented with Pichia membranaefaciens, Kloeckera apiculata, Candida valida and S. cerevisiae [102]. This study demonstrated the differences in the production of VOCs including ethyl acetate, isoamyl acetate, acetaldehyde, 2-methyl propanol and 3-methyl butanol. P. membranaefaciens was deemed to be the most suitable yeast to produce sparkling wines due to the sensory panels' preference, in comparison to S. cerevisiae wines. González-Royo et al. [35] studied sequential fermentations of T. delbrueckii and M. pulcherrima with S. cerevisiae to determine their effect on the chemical composition on base wine of $V$. vinifera cv. Macabeo grapes. Some significant differences were observed in comparison to solitary fermentations with S. cerevisiae: higher alcohols (3-methyl-1-butanol), acetaldehyde and major esters, minor esters (butyl acetate) and lactones (g-decalactone). Nevertheless, no major differences were reported in the aromatic profile of the wines. Canonico et al. [51] studied the effect of T. delbrueckii in second fermentation of Verdicchio base wine. Two T. delbrueckii strains and a strain of S. cerevisiae were used in both pure and mixed cultures. Significant differences were detected in hexanol, ethyl hexanoate, isoamyl acetate, ethyl octanoate and ethyl butyrate production. VOCs of white and red 
sparkling wines produced with S. pombe and S. ludwigii were compared to S. cerevisiae [52] and no significant differences were reported in the total concentration of VOCs, although specific VOC families (esters, acetoin metabolites and higher alcohols) were found to be significantly different (Table 2). Differences in VOCs reported in studies could be a result of the nitrogen preferences of the yeasts due to their specific amino acid consumption profiles [67].

Table 2. Volatile aroma compounds (VOCs) studied in base wines and sparkling wines produced with non-Saccharomyces yeasts.

\begin{tabular}{|c|c|c|c|c|}
\hline Yeast & Production Stage & $\begin{array}{l}\text { Higher Production in } \\
\text { Comparison to S. cerevisiae }\end{array}$ & $\begin{array}{c}\text { Lower Production in } \\
\text { Comparison to S. cerevisiae }\end{array}$ & Reference \\
\hline $\begin{array}{l}\text { T. delbrueckii + } \\
\text { S. cerevisiae }\end{array}$ & \multirow[b]{2}{*}{$\begin{array}{l}\text { First fermentation } \\
\text { for base wine } \\
\text { production }\end{array}$} & $\begin{array}{l}\text { Total higher alcohols } \\
\text { Total lactones } \\
\text { 3-methyl-1-butanol } \\
\text { 2-methylpropanol } \\
\text { 1-butanol } \\
\text { 2-phenyl ethyl acetate }\end{array}$ & $\begin{array}{c}\beta \text {-phenylethanol } \\
\text { 1-hexanol } \\
\text { Ethyl lactate } \\
\text { Ethyl decanoate } \\
\text { Ethyl octanoate }\end{array}$ & \multirow[b]{2}{*}[35]{} \\
\hline $\begin{array}{l}\text { M. pulcherrima }+ \\
\text { S. cerevisiae }\end{array}$ & & $\begin{array}{c}\text { Total higher alcohols } \\
\text { Total major esters } \\
\text { Total minor esters } \\
\text { Total lactones } \\
\text { 3-methyl-1-butanol } \\
\text { 2-methylpropanol } \\
\text { Diethyl succinate 2-phenyl } \\
\text { ethyl acetate } \\
\text { Ethyl isovalerate } \\
\text { Methyl vanillate }\end{array}$ & $\begin{array}{l}\text { Methionol } \\
\text { Acetaldehyde } \\
\text { Ethyl lactate } \\
\text { Ethyl decanoate } \\
\text { Ethyl acetate } \\
\text { Ethyl octanoate } \\
\text { Butyl acetate } \\
\text { Linalool acetate }\end{array}$ & \\
\hline S. ludwigii 979 & \multirow{2}{*}{$\begin{array}{c}\text { Second } \\
\text { fermentation in } \\
\text { bottle }+4 \text { months } \\
\text { of aging on lees }\end{array}$} & $\begin{array}{c}\text { Diacetyl } \\
\text { Acetoin } \\
\text { 2-methyl-1-butanol } \\
\text { Ethyl acetate }\end{array}$ & $\begin{array}{l}\text { Acetaldehyde } \\
\text { 2.3-butan-ediol } \\
\text { Isoamyl acetate }\end{array}$ & \multirow[t]{2}{*}{ [52] } \\
\hline S. pombe 938 & & Acetoin & $\begin{array}{l}\text { Isoamyl acetate } \\
\text { 2.3-butan-ediol }\end{array}$ & \\
\hline T. delbrueckii 130 & \multirow{4}{*}{$\begin{array}{c}\text { Second } \\
\text { fermentation in } \\
\text { bottle }+12 \text { months } \\
\text { of aging on lees }\end{array}$} & $\begin{array}{c}\text { Ethyl hexanoate } \\
\text { Ethyl octanoate } \\
\text { Isoamyl acetate } \\
\text { Hexanol }\end{array}$ & $\begin{array}{l}\text { Acetaldehyde } \\
\text { n-propanol } \\
\text { Isobutanol } \\
\text { Isoamyl alcohol }\end{array}$ & \multirow{4}{*}[51]{} \\
\hline T. delbrueckii 313 & & $\begin{array}{l}\text { Ethyl hexanoate } \\
\text { Ethyl octanoate } \\
\text { Isoamyl acetate } \\
\text { Hexanol }\end{array}$ & $\begin{array}{l}\text { Acetaldehyde } \\
\text { Ethyl butyrate } \\
\text { n-propanol } \\
\text { Isobutanol } \\
\text { Isoamyl alcohol } \\
\end{array}$ & \\
\hline $\begin{array}{c}\text { S. cerevisiae }+ \\
\text { T. delbrueckii } 130\end{array}$ & & $\begin{array}{l}\text { Ethyl hexanoate } \\
\text { Ethyl octanoate }\end{array}$ & $\begin{array}{l}\text { Acetaldehyde } \\
\text { Ethyl butyrate } \\
\text { Ethyl acetate } \\
\text { n-propanol } \\
\text { Isobutanol } \\
\text { Isoamyl alcohol }\end{array}$ & \\
\hline $\begin{array}{l}\text { S. cerevisiae }+ \\
\text { T. delbrueckii } 313\end{array}$ & & $\begin{array}{l}\text { Ethyl hexanoate } \\
\text { Ethyl octanoate } \\
\text { Isoamyl acetate } \\
\text { Hexanol }\end{array}$ & $\begin{array}{l}\text { Acetaldehyde } \\
\text { Ethyl butyrate } \\
\text { Ethyl acetate } \\
\text { n-propanol } \\
\text { Isobutanol } \\
\text { Isoamyl alcohol }\end{array}$ & \\
\hline
\end{tabular}

\section{Yeast-Derived Proteins}

It is important to note that the definition of yeast mannoproteins is contentious in literature because they are referred to as both mannoproteins and polysaccharides [103]. Yeast mannoproteins are glycoproteins, which belong to the proteoglycan family and contain $10 \%$ protein and $90 \%$ 
mannose [104,105]. Proteins are important compounds in foaming ability and foaming stability even though they are present at low concentrations in sparkling wines $(4-16 \mathrm{mg} / \mathrm{L})$ [103].

The yeast mannoproteins/polysaccharides are located in the outermost layer of the yeast cell wall linked by $\beta-1,3$ glycan chains to the innermost fibrous layer and formed from $\beta-1,3$ glycan and chitin [106-108]. They are released from the yeast cell wall during alcoholic fermentation and aging in contact with yeast lees. They represent one of the major polysaccharides found in wine [109]. S. pombe has only been considered for use in sparkling wine production as a base wine deacidification tool. However, its' ability to reduce lees aging has already been demonstrated in red wines through the rapid release of its' cell wall mannoproteins, due to its fast autolytic activity [110].

The unique mannoprotein profiles of non-Saccharomyces yeast (Hansensiaspora osmophila, L. thermotolerans, M. pulcherrima, Pichia fermentans, S. ludwigii, Starmerella bacillaris, T. delbrueckii and Zygosaccharomyces florentinus) have been isolated and characterized by Domizio et al. [109]. A synthetic, polysaccharide-free grape juice was used to characterize their release during alcoholic fermentation of still table wines. All strains showed a different intensity for each glycan and a core of N-glycans with a mass ranging in size from 8-15 mannoses was determined. We know that mannoproteins increase the mouthfeel properties of wine [111] and proteins contribute to sweet and bitter tastes as well as playing an important role in foam stability [112]. However, it appears vague from current literature, which non-Saccharomyces yeast, species, proteins and/or strains, contribute to the sweet, and/or bitter tastes. It is also unclear how their unique protein profiles contribute to sparkling wine composition during aging, particularly with relation to haze-related proteins.

T. delbrueckii had a positive effect on the foaming properties of cava wines, when used for the first fermentation, while M. pulcherrima increased foam stability [35]. Sequential inoculation (T. delbrueckii and S. cerevisiae) produced base wines with higher foaming potential than S. cerevisiae alone [36]. This was undoubtedly due to the greater release of proteins from T. delbrueckii cells compared to S. cerevisiae, particularly the low molecular weight (LMW) fraction.

Further consideration for future sparkling wine studies could be the enzyme production by non-Saccharomyces yeasts and their effect on sparkling wine, although it is difficult to distinguish between compounds synthesized from enzyme activity, and the compounds released from cells through yeast autolysis. Most noticeably missing from our current knowledge is the effect of non-Saccharomyces yeast on the protein evolution and foam qualities of sparkling wines following a long period of cellar aging when wines are in contact with yeast lees. Current studies have only reported on results of non-Saccharomyces influence on wine after short aging periods but many traditional method sparkling wines can spend long periods of time in the cellar (i.e., 2-10 years). Importantly, the practical implications during wine production, of high protein concentrations in bottles concerning haze formation, riddling, disgorging and gushing have so far, not been investigated.

\section{Organic Acids}

Some non-Saccharomyces yeasts have the ability to reduce alcohol [113], tolerate low temperature fermentations [114], influence aroma compounds and the wines' sensory profile, increase glycerol yield and specific strains can be used to target particular organic acids $[115,116]$. MLF can be carried out in sparkling base wines to alter the organic acid ratio by converting malic acid to lactic acid. Because of its malic dehydrogenase activity, the non-Saccharomyces yeast most exploited for this is S. pombe. Additionally, S. pombe produces less urea and more pyruvic acid than Saccharomyces species. Three of four Schizosaccharomyces strains completed the breakdown of malic acid by day four of a red wine fermentation [110]. The main negative effect of $S$. pombe is strong acetic acid production, which is most likely the reason for its lack of use in second fermentation. Nevertheless, a recent study by Ivit et al. [52] reported that $78 \%$ of malic acid was metabolized by S. pombe during the fermentation in bottle. In contrast to S. pombe, L. thermotolerans is a low producer of acetic acid though the level of production tends to be strain dependent and it does not always complete sugar consumption, which could be problematic for in-bottle fermentation $[19,117]$. Mixed-fermentations of non-Saccharomyces 
yeast produce less MCFA, known inhibitors of MLF [118]. T. delbrueckii has also been found to slightly reduce malic acid levels in wine by approximately 20\% [119] and 25\% [40] but Loira et al. [34] reported no effect, demonstrating the influence of yeast strain on malic acid consumption. T. delbrueckii increased succinic acid in sequential inoculations but this acid contributes to undesirable bitter/salty flavors to wine $[120,121]$. On the other hand, pyruvic acid is produced at high concentrations by T. delbrueckii [119] and this acid can improve MLF performance by Oenococcus oeni by acting as an external electron acceptor facilitating the production of NAD+ [118,122]. Benito et al. [123] and Ivit et al. [52] both reported differences in pyruvic acid production amongst non-Saccharomyces yeast. Pyruvic acid is involved in the formation of stable pigments i.e., pyranoanthocyanins [124], which could have implications for the color stability of rosé sparkling wines. Significant differences in total acidity were found (reported as tartaric acid) between yeasts in the study by Ivit et al. [52], due to malic acid changes during fermentation.

\section{Effect of Non-Saccharomyces Yeasts on Sparkling Wine Sensory Profiles}

Sensory analysis continues to be an efficient tool for assessing the sensory properties of sparkling wines [125]. However, there is lack of an internationally accepted or recognized sensory analysis method specifically for sparkling wines, as well as published criteria to evaluate effervescence and foam properties of sparkling wines [126]. Sensory evaluation of sparkling wines has been carried out using tasting cards, proposed by the OIV (Office International de la Vigne et du Vin, 1994) for international wine competitions, then partially modified by the Instituto Nacional de Denominaciones de Calidad of the Spanish Ministry of Agriculture, Fisheries and Food [63,127,128]. The method evaluates attributes by scoring them according to the following method: visual aspects carried a weight of 1 , intensity and quality of aroma and intensity of taste 2 and finally quality of taste and harmony carried a weight of 3 . Visual aspect of the wines, along with the color and foam characteristics were also evaluated [127].

McMahon et al. [129] evaluated sparkling wines, which were sweetened to different sugar levels, using a trained panel and consumer panel. Aroma attributes (nasal pungency, fruity, floral, green, yeasty and toasted); flavor attributes (fruity, floral, green, yeasty and toasted); taste attributes (sweet, sour and bitter); and mouthfeel attributes (bubble pain, foamy and creamy) were used. López de Lerma et al. [130] used descriptive analysis to evaluate color, odor and taste descriptors of sparkling wines that were produced with different yeast strains. The sensory attributes used in their study included: color quality, aroma quality, aroma intensity, fruity, yeasty and mold aroma and in terms of the taste, intensity and quality, acidity, body and bitterness. The authors classified into nine aroma groups; chemistry, fruity, toasty, green fruit, citrus, floral, fatty, creamy, herbaceous [130]. Few studies take into consideration how the $\mathrm{CO}_{2}$ in sparkling wine may affect odor detection when compared to the same VOC in an aqueous, still wine or ethanolic solution [3]. The concentration of dissolved $\mathrm{CO}_{2}$ effects the sensory properties including the frequency of bubble formation in the glass, the growth rate of rising bubbles, mouthfeel and the aromatic perception [131]. The attributes used for describing foam quality and effervescence include; the initial quantity of foam formed upon pouring, the appearance of the foam across the surface of the wine, the presence of foam collar, bubble size and duration of the bubble formation and foam stability [132,133].

\subsection{Sensory Effects of Non-Saccharomyces Yeasts on Sparkling Wines}

The influence of non-Saccharomyces yeasts on the sensory profile of wines is of great interest in current research [99]. Non-Saccharomyces yeasts possess special metabolic characteristics that affect the organoleptic profile of wines [24]. The sensory effects of non-Saccharomyces yeasts on base wines, second fermentation and aging on lees have been investigated [35,36,51,52].

González-Royo et al. [35] conducted two triangle tests and a preference test to evaluate the effect of sequential inoculations with T. delbrueckii or M. pulcherrima and S. cerevisiae versus S. cerevisiae fermentation only. A group of nine people from the Rovira i Virgili University conducted the sensory 
tests. Six out of nine tasters were able to distinguish between the base wines produced with sequential inoculation by T. delbrueckii and the S. cerevisiae wines. Five of the six tasters successfully differentiated the wines and preferred wines produced from the sequential inoculation of T. delbrueckii. In the case of M. pulcherrima, eight out of nine tasters were able to distinguish between the wines, the preference was equal; four preferred the $S$. cerevisiae wines, while the other four preferred the wine fermented using a sequential inoculation. Five of the eight tasters who successfully differentiated the wines, associated smoky and flowery aromas with the wine fermented by sequential inoculation with $M$. pulcherrima. The smoky perception was associated with the higher production of 2,6-dimethoxyphenol, flowery notes could not be associated with any of the measured VOCs [35].

The base wines produced in the study by González-Royo et al. [35] and were used to produce sparkling wines by Medina-Trujillo et al. [36]. A triangle test and a preference test with a group of twelve oenologists from the Rovira i Virgili University were conducted, to compare sparkling wines produced from the base wine of the sequential fermentation of T. delbrueckii and S. cerevisiae with those fermented only with $S$. cerevisiae. Nine out of twelve tasters were able to identify the wines produced by sequential inoculation with T. delbrueckii. Additionally, six of the nine tasters who successfully identified the wines, preferred the sparkling wine made from the sequential inoculation. This was because they found that the effervescence was more integrated and the wines had a less aggressive mouthfeel. The results concerning effervescence was related to improved foam properties specifically higher maximum foam height and higher amounts of proteins, especially LMW fraction [36].

The two studies of González-Royo et al. [35] and Medina-Trujillo et al. [36] confirmed that the base wine characteristics carry through to the finished sparkling wines. Unfortunately, though, Medina-Trujillo et al. [36] did not include base wines produced by a sequential inoculation of M. pulcherrima in the study from González-Royo et al. [35]. Similar to González-Royo et al. [35], the triangle test followed a preference test in the study of Medina-Trujillo et al. [36]. However, there was a higher number of panelists in one [36] than in the other [35]. In both studies of the base and finished sparkling wines, the majority of the panelists were able to distinguish wine produced from the sequential inoculation by T. delbrueckii. Sensory evaluation of white sparkling wines made from $V$. vinifera cv. Airén grapes, as well as red sparkling wines of $V$. vinifera cv. Tempranillo grapes, both made with either non-Saccharomyces yeasts or S. cerevisiae for the second fermentation [52]. To assess the final wines a descriptive sensory analysis was conducted using pre-determined scorecards. The scorecards consisted of fifteen attributes, including visual, olfactory and mouthfeel attributes as well as the overall perceived quality. The panel consisted of 11 experienced people from Polytechnic University of Madrid (age range from 27 to 57 years, four women and seven men). In both white and red wines, those produced from non-Saccharomyces yeasts showed significantly more limpidity compared to those produced from $S$. cerevisiae. In the red wines, highest effervescence was found in the sparkling wines produced with S. ludwigii, while the highest color intensity was reported for those produced with S. pombe. The white sparkling wines produced using $S$. cerevisiae were perceived as having significantly higher aroma quality compared to those produced from non-Saccharomyces yeasts. Higher aroma intensity scores were also reported for white sparkling wines produced from S. ludwigii, while in red samples those with $S$. pombe. White sparkling wines produced with $S$. pombe had higher scores for buttery and yeasty aromas and lower scores for flowery and fruity aromas. The red wines made from $S$. pombe had the highest scores for herbal, buttery, yeasty, acetic acid and oxidation aromas. Higher scores for buttery aromas were related to higher diacetyl production (characterized by buttery aromas with a threshold value of 0.1-5 mg/L) [75]. Wines made from non-Saccharomyces yeasts scored lower for fruity aromas in white sparkling wines, purportedly due to lower ester production by the yeasts. Crucially, the length of time aging on lees was only 4 months, while traditional method sparkling wines are subjected to longer aging periods. Further studies over longer periods are necessary to be able to evaluate the effect of non-Saccharomyces yeasts on the organoleptic characteristics of the wines.

Verdicchio base wine fermented in bottle with fermentations of two different $T$. delbrueckii strains, a mixed fermentation of $T$. delbrueckii strains with $S$. cerevisiae versus wines fermented only with 
S. cerevisiae was carried out. The sensory analysis was carried out using a pre-determined list of descriptors and a scale of 1 to 10. The aromatic attributes (e.g., floral, fruity, toasty) and the main structural features (e.g., sweet, acidity, flavor, astringency, bitterness, olfactory persistence) were evaluated. The panel consisted of 10-trained tasters. For the main sensorial descriptors, significant differences were reported for mixed fermentations and pure fermentation of T. delbrueckii strains in comparison to S. cerevisiae wines. The sparkling wines produced with pure fermentation of T. delbrueckii 130 strain was characterized by the sensorial attributes of white flowers, bread crust, sapidity and acidity and were significantly different from the other wines, except for the attribute "sapidity" (the savory flavor associated with wine). Sparkling wines produced with both T. delbrueckii strains in pure and mixed fermentations obtained higher scores for the aromatic descriptors of white flowers, citrus, honey, odor intensity and softness in comparison with the control sparkling wines. These results were in agreement with the respective volatile compounds measured, since samples showed higher amounts of ethyl butyrate, ethyl hexanoate, ethyl octanoate and isoamyl acetate. Wines produced from the pure fermentation of S. cerevisiae obtained significantly higher scores for astringency [51]. However, components that contribute to astringency in wine such as phenolic compounds were not measured so it is unclear which compounds were responsible for these results.

The following paragraph discusses the sensory effects of non-Saccharomyces yeasts on both base wines and sparkling wines beginning with sequential fermentation (Table 3). González-Royo et al. [35] showed the effect of sequential fermentations of T. delbrueckii and M. pulcherrima on base wines. The majority of the panelists preferred base wines produced from sequential fermentations of T. delbrueckii over the wines made only with $S$. cerevisiae. The effect of sequential fermentations using T. delbrueckii for first fermentation on the corresponding traditional method sparkling wine was investigated by Medina-Trujillo et al. [36]. In this case, the majority of panelists preferred sparkling wines produced from sequential fermentations of T. delbrueckii.

Table 3. Summary of the impact of non-Saccharomyces yeasts on sensory profiles of base wines and sparkling wines.

\begin{tabular}{|c|c|c|c|c|}
\hline Yeast & Production Stage & $\begin{array}{c}\text { Sensory } \\
\text { Evaluation }\end{array}$ & Effect on the Sensory Profile & Reference \\
\hline $\begin{array}{l}\text { T. delbrueckii }+ \\
\text { S. cerevisiae }\end{array}$ & \multirow{2}{*}{$\begin{array}{l}\text { First fermentation } \\
\text { for base wine } \\
\text { production }\end{array}$} & \multirow{2}{*}{$\begin{array}{l}\text { Sensory triangle } \\
\text { test, panel with } \\
\quad 9 \text { tasters }\end{array}$} & $\begin{array}{l}\text { It was distinguishable by } 6 \text { of the } 9 \text { tasters and } 5 \text { of them } \\
\text { preferred them over control wine. }\end{array}$ & \multirow[b]{2}{*}{ [35] } \\
\hline $\begin{array}{l}\text { M. pulcherrima }+ \\
\text { S. cerevisiae }\end{array}$ & & & $\begin{array}{c}\text { It was distinguishable by } 8 \text { of the } 9 \text { tasters and } 4 \text { of them } \\
\text { preferred them over control wine. Smoky and } \\
\text { flowery aromas. }\end{array}$ & \\
\hline $\begin{array}{l}\text { T. delbrueckii } \\
\text { (sequential } \\
\text { inoculation with } \\
\text { S. cerevisiae) }\end{array}$ & $\begin{array}{l}\text { First fermentation } \\
\text { followed by a } \\
\text { second } \\
\text { fermentation }\end{array}$ & $\begin{array}{l}\text { Sensory triangle } \\
\text { test, panel with } \\
12 \text { tasters }\end{array}$ & $\begin{array}{l}\text { It was distinguishable by } 9 \text { of the } 12 \text { tasters and } 8 \text { of } \\
\text { them preferred them over control wine. Better integrated } \\
\text { effervescence and less aggressiveness in the mouth. }\end{array}$ & [36] \\
\hline S. ludwigii 979 & \multirow{2}{*}{$\begin{array}{l}\text { Second } \\
\text { fermentation in } \\
\text { bottle }+4 \text { months } \\
\text { of aging on lees }\end{array}$} & \multirow{2}{*}{$\begin{array}{l}\text { Prepared } \\
\text { evaluation sheet, } \\
\text { panel with } \\
11 \text { tasters }\end{array}$} & $\begin{array}{c}\text { In the red sparkling wines, higher limpidity and } \\
\text { effervescence, in white sparkling wines higher limpidity } \\
\text { but lower aroma intensity and quality in comparison } \\
\text { to control. }\end{array}$ & \multirow[b]{2}{*}{ [52] } \\
\hline S. pombe $7 V A$ & & & $\begin{array}{l}\text { In red sparkling wines, higher aroma intensity and } \\
\text { higher scores for herbal, buttery, yeasty, acetic acid and } \\
\text { oxidation aromas, in white sparkling wines higher } \\
\text { limpidity; lower aroma quality, higher buttery, yeasty } \\
\text { and reduction; lower flowery and fruity aromas in } \\
\text { comparison to control. }\end{array}$ & \\
\hline T. delbrueckii 130 & \multirow{4}{*}{$\begin{array}{l}\text { Second } \\
\text { fermentation in } \\
\text { bottle }+12 \text { months } \\
\text { of aging on lees }\end{array}$} & \multirow{4}{*}{$\begin{array}{l}\text { Prepared } \\
\text { evaluation sheet, } \\
\text { panel with } \\
11 \text { tasters }\end{array}$} & $\begin{array}{l}\text { It was characterized for the sensorial attributes of white } \\
\text { flowers, bread crust, sapidity and acidity, with } \\
\text { significant differences from other sparkling wines, } \\
\text { except the attribute of sapidity. }\end{array}$ & \multirow{4}{*}{ [51] } \\
\hline T. delbrueckii 313 & & & Significant differences were detected in the main sensory & \\
\hline $\begin{array}{l}\text { S. cerevisiae }+ \\
\text { T. delbrueckii } 130\end{array}$ & & & $\begin{array}{l}\text { attributes in comparison to control wine. Higher scores } \\
\text { for the aromatic descriptors (white flowers, citrus, honey, } \\
\text { odor intensity, softness). Control wine showed }\end{array}$ & \\
\hline $\begin{array}{l}\text { S. cerevisiae }+ \\
\text { T. delbrueckii } 313\end{array}$ & & & $\begin{array}{c}\text { significantly higher astringency in comparison to all } \\
\text { other studied fermentations. }\end{array}$ & \\
\hline
\end{tabular}




\subsection{Sensorial Influence from Lees Aging}

During aging on lees, the organoleptic properties of sparkling wines evolve due to yeast autolysis, wine chemical composition, enzyme activity and the subsequent range of compounds that are released during storage [64]. Vannier et al. [125] and Torrens et al. [134] both evaluated the olfactory descriptors of panelists, who evaluated champagne and cava wines respectively. Champagne and cava sparkling wines both age on yeast lees but for different lengths of time, depending on their styles. The grape varieties in the two differ because, champagne wines are mainly made from Chardonnay, Pinot noir and Pinot meunier [135], while Macabeu, Xarel-lo and Parellada are the main varieties used in cava production [8]. According to Vannier et al. [125], the herbaceous and exotic fruit aromas decreased in champagne wines, while chemical, yeasty, butter and toasty notes increased during aging. Descriptors of base wine versus finished cava wines found that the profile of the wines were more complex than that of the base wine [134]. Many studies have been conducted to show the effect of non-Saccharomyces yeast on still wines and their effects on the wines' sensorial properties. Results of these studies can be transferred to traditional method sparkling wines.

T. delbrueckii is one of the most widely studied non-Saccharomyces yeasts. It is used already on an industrial scale in wine production [51]. Tempranillo wines made from sequential fermentations of T. delbrueckii and S. cerevisiae were evaluated by descriptive sensory analysis [34]. The six panelists used a scale from 0 to 10 to rate the overall perception and aromatic quality of the wines. T. delbrueckii strains in sequential fermentations, performed better than S. cerevisiae alone. Significant differences in aromatic quality from sensory evaluation of several fermentations with $T$. delbrueckii were correlated with tgreater production of several VOCs measured including esters, diacetyl and 3-ethoxy propanol [34]. More recently, Belda et al. [37] compared Verdejo wines fermented by co-inoculation of T. delbrueckii with S. cerevisiae to wines made using only S. cerevisiae. A panel of ten experienced wine tasters (members of the staff of the Food Technology Department of the Polytechnic University of Madrid and Microbiology Department of the Complutense University of Madrid) assessed the wines. Following the generation of attributes, twelve were chosen to describe the wines using a $10 \mathrm{~cm}$ unstructured scale. The authors reported that wines produced using T. delbrueckii, had a higher aroma quality, intensity and fruity character than the other wines. This result was accredited to a significant increase in varietal thiols, especially 4-MSP and in 2-phenylethyl, along with the lower values of higher alcohols. Marcon et al. [38] also reported a positive effect on Moscato Branco wines fermented by co-inoculation of $T$. delbrueckii with $S$. cerevisiae. The descriptive sensory attributes included visual and olfactory terms (aroma intensity and gustatory), were scored with an intensity scale $(0-5)$, while the general sensory quality was scored from 0 to 100 . The positive contribution of co-inoculation of T. delbrueckii with $S$. cerevisiae was again related to the increase in ester concentrations, and the reduction in higher alcohols and volatile fatty acids [38]. These studies show the positive effects of T. delbrueckii on sensory properties of still wines, which could be of interest for sparkling wines, although their concentrations during aging and interaction with autolytic flavor compounds need to be monitored.

In the study of Benito et al. [29] the sequential fermentation using S. cerevisiae and three non-Saccharomyces yeasts (P. kluyveri, L. thermotolerans, or M. pulcherrima) was carried out using Riesling grapes. A sensory evaluation by a panel of thirteen participants (staff of the Department of Microbiology and Biochemistry of the Hochschule Geisenheim University, Germany) used 17 attributes and a ten-point scale. These wines produced from non-Saccharomyces yeast had higher scores for overall impression and fruitiness, while those with S. cerevisiae had the lowest score for aroma quality but highest scores for ethyl acetate, acetaldehyde and oxidation. The high scores for acetaldehyde in sensory evaluation were corroborated chemical data that confirmed high values of acetaldehyde in the wines.

\subsection{Glycerol}

As a by-product of fermentation, glycerol is one of the compounds, after water and ethanol, that is found at the highest concentrations in wine $(5-20 \mathrm{~g} / \mathrm{L})$. The concentration of glycerol in wine may 
change depending on the vinification conditions such as temperature, aeration, sulphite level and yeast strains [58]. In still table wines, glycerol content has been found to contribute positively to mouthfeel and Jolly et al. [136] states that some non-Saccharomyces strains positively influence wine quality. In the case of sparkling wine, glycerol content affects viscosity, foaming and VOCs [3] with a high concentration of glycerol in base wines having a negative synergistic effect with ethanol that could retard completion of the second alcoholic fermentation [58].

Increases in glycerol concentrations were one of the first recognized effects of non-Saccharomyces yeast species in fermentation winemaking [18]. Borrull et al. [58] determined the effect of glycerol levels on the growth of yeast strains in the presence of ethanol. The effect of 0,5 and $10 \mathrm{~g} / \mathrm{L}$ of glycerol was studied in the basal growth medium with $0 \%, 10 \%$ and $15 \%(v / v)$ of ethanol. The results showed that the glycerol concentration of $5 \mathrm{~g} / \mathrm{L}$ did not modify the behavior of yeast strains in the absence or presence of ethanol. However, $10 \mathrm{~g} / \mathrm{L}$ of glycerol concentration significantly affected it, regardless of the ethanol concentration. This caused a lower maximum growth rate and the initiation of the growth stage was longer than usual. The study concluded that a high glycerol level in the base wine could impact the second alcoholic fermentation and may even cause stuck fermentations [58]. The yeasts that produce a high amount of glycerol during fermentation, such as S. kudriavzeviii [137], would probably prevent a successful second fermentation [58]. Non-Saccharomyces yeast species that have been described as high glycerol producers include T. delbruckii, Candida zeylanoides, Candida stellata, Starmerella bacillaris (synonym Candida zemplinina) and L. thermotolerans [19,35-37,42,45,49,120,138].

Glycerol concentrations reported in wines produced from $S$. cerevisiae have been in the range of 4.5-9.9 g/L [57,139], while non-Saccharomyces yeast have been found to produce concentrations of 8.3-10.5 g/L for wines (S. japonicas) and 9-11.4 g/L for S. pombe strains [139].

Benito et al. [44] found similar results from different $S$. pombe strains. Although two of the strains showed the highest values of glycerol, the other strains produced similar results to S. cerevisiae (8.02-8.91 g/L). Additionally, M. pulcherrima, increased glycerol concentrations, without increasing volatile acidity and acetaldehyde in the final wine [49].

Sequential fermentations with non-Saccharomyces yeasts, including Kluyveromyces thermotolerans, P. kluyveri and M. pulcherrima, produced higher amount of glycerol in comparison to S. cerevisiae [29]. The levels of glycerol varied from 5.8 to $6.3 \mathrm{~g} / \mathrm{L}$ [29]. T. delbrueckii is a yeast that produces lower levels of glycerol than other non-Saccharomyces yeasts $[140,141]$. Mixed fermentations with non-Saccharomyces yeasts, including T. delbrueckii, was studied by Comitini et al. [19]. The mixed fermentations with non-Saccharomyces yeasts produced high amounts of glycerol were reported. However, similar amounts of glycerol were produced from the mixed fermentation of T. delbrueckii $(5.88 \mathrm{~g} / \mathrm{L}$ to $6.29 \mathrm{~g} / \mathrm{L}$ and the sole fermentation of S. cerevisiae ( $6.23 \mathrm{~g} / \mathrm{L}$ to $6.65 \mathrm{~g} / \mathrm{L})$. Glycerol content of sparkling wines produced with $T$. delbrueckii showed significantly higher glycerol values in comparison to sparkling wines produced with S. cerevisiae in a study by González-Royo et al. [35]. White sparkling wines produced with S. ludwigii have been found to have significantly higher concentrations of glycerol $(4.95 \mathrm{~g} / \mathrm{L})$ in comparison to those produced with S. cerevisiae and S. pombe $(4.57 \mathrm{~g} / \mathrm{L}$ and $4.67 \mathrm{~g} / \mathrm{L}$ respectively). Interestingly, the glycerol content of red sparkling wines ranged between $4.89 \mathrm{~g} / \mathrm{L}$ to $5.12 \mathrm{~g} / \mathrm{L}$ without any significant differences [52]. It is apparent from these results that glycerol concentrations in sparkling wines made from non-Saccharomyces yeast differ depending on yeast species and strain, and whether the yeast is used alone, or in combination with another yeast species. Importantly, uncertainty surrounding the long-term effect on sparkling wine foam and mouthfeel remains due to negative perceptions associated with increased mouthfeel in high quality sparkling wines.

\section{Conclusions and Further Research}

The nutrient requirement differences of non-Saccharomyces yeasts from their preference for either ammonium and/or amino acids suggests an area for further research in combination with the nitrogen requirements of a co-inoculation fermentation for first and/or second fermentation. Some non-Saccharomyces yeasts have been used to decrease the biogenic amount of sparkling wines 
although, further studies are needed to study their effect on biogenic amine concentrations after several years of lees aging. Non-Saccharomyces yeasts can influence the aromas of sparkling wines through production of enzymes and metabolites during aging in contact with yeast lees. Non-Saccharomyces yeasts have shown significant differences in numerous VOCs between species and strains. The studies on sensory effects of non-Saccharomyces yeasts on sparkling wines have found that the use of yeasts as sole inoculations, or in mixed fermentations to obtain specific sensory attributes and distinctive characters is possible. However, the studies so far, conducted have used relatively short lees aging times (4,6 and 12 months). The ability to reduce alcohol levels by some yeasts could be beneficial to warm climate sparkling wine producers. However, our knowledge of their effect on sparkling wine practical production stages (i.e., riddling, disgorging), foam stability, flavor and aroma in wines that have been aged for long periods of cellar aging is limited. A major challenge to overcome is their acceptance by sparkling winemakers and established brands. With further research these yeasts when combined, provide a point of difference for small sparkling wine producers. The related topic of interspecific hybridization, and encapsulation of non-Saccharomyces yeast have not been considered in our review but are both areas that necessitate consideration in sparkling wine research.

Author Contributions: The authors contributed equally to the writing of the paper.

Acknowledgments: The authors would like to thank Perennia Food and Agriculture Inc., Nova Scotia, Canada, Acadia University, Nova Scotia, Canada and the Cool Climate Oenology and Viticulture Institute (CCOVI), Brock University, Canada for their support. We would like to acknowledge the contribution of Jeff Graham and Mike Matyjewicz (Sparkling Winos) for their drawing of sparkling wine bottles that appears in the graphical abstract for this paper.

Conflicts of Interest: The authors and Perennia Food and Agriculture Inc. declare no conflict of interest.

\section{References}

1. Jackson, R.S. Specific and Distinctive Wine Styles. In Wine Science: In Principles and Applications; Academic Press/Elsevier: Hoboken, NJ, USA, 2014; pp. 677-759.

2. Vigentini, I.; Cardenas, S.B.; Valdetara, F.; Faccincani, M.; Panont, C.A.; Picozzi, C.; Foschino, R. Use of Native Yeast Strains for In-Bottle Fermentation to Face the Uniformity in Sparkling Wine Production. Front. Microbiol. 2017, 8, 1225. [CrossRef] [PubMed]

3. Kemp, B.; Alexandre, H.; Robillard, B.; Marchal, R. Effect of production phase on bottle-fermented sparkling wine quality. J. Agric. Food Chem. 2015, 14, 19-38. [CrossRef] [PubMed]

4. Pérez-Magariño, S.; Ortega-Herasa, M.; Bueno-Herrera, M.; Martínez-Lapuente, L.; Guadalupe, Z.; Ayestarán, B. Grape variety, aging on lees and aging in bottle after disgorging influence on volatile composition and foamability of sparkling wines. LWT-Food Sci. Technol. 2015, 61, 47-55. [CrossRef]

5. Martínez-García, R.; García-Martínez, T.; Puig-Pujol, A.; Mauricio, J.C.; Moreno, J. Changes in sparkling wine aroma during the second fermentation under $\mathrm{CO}_{2}$ pressure in sealed bottle. Food Chem. 2017, 237, 1030-1040. [CrossRef] [PubMed]

6. Pozo-Bayón, M.A.; Martínez-Rodríguez, M.; Pueyo, E.; Moreno-Arribas, M.V. Chemical and biochemical features involved in sparkling wine production: From a traditional to an improved winemaking technology. Trends Food Sci. Technol. 2009, 20, 289-299. [CrossRef]

7. Torresi, S.; Frangipane, M.T.; Anelli, G. Biotechnologies in sparkling wine production. Interesting approaches for quality improvement: A review. Food Chem. 2011, 129, 1232-1241. [CrossRef] [PubMed]

8. Riu-Aumatell, M.; Torrens, J.; Buxaderas, S.; López-Tamames, E. Cava (Spanish sparkling wine) aroma: Composition and determination methods. In Recent Advances in Pharmaceutical Sciences III; Muñoz-Torrero, D., Cortés, A., Mariño, E.L., Eds.; Transworld Research Network: Kerala, India, 2013; pp. 45-60.

9. Caliari, V.; Burin, V.M.; Rosier, J.P.; BordignonLuiz, M.T. Aromatic profile of Brazilian sparkling wines produced with classical and innovative grape varieties. Food Res. Int. 2014, 62, 965-973. [CrossRef]

10. Mafata, M. The Effect of Grape Temperature on The Phenolic Extraction and Sensory Perception of Méthode Cap Classique Wines. Ph.D. Thesis, Stellenbosch University, Stellenbosch, South Africa, March 2017.

11. Buxaderas, S.; López-Tamames, E. Sparkling wines: Features and trends from tradition. Adv. Food Nutr. Res. 2012, 66, 1-45. [CrossRef] [PubMed] 
12. Duteurtre, B. Assemblage. In Le Champagne: De La Tradition à La Science; Lavoisier/Tec \& Doc: Paris, France, 2006; pp. 116-125.

13. Ribéreau-Gayon, P.; Dubourdieu, D.; Doneche, B.; Lonvaud, A. Other Winemaking Methods. In Handbook of Enology, the Microbiology of Wine and Vinifications, 2nd ed.; John Wiley and Sons Ltd.: Hoboken, NJ, USA, 2006; pp. 445-480.

14. Duteurtre, B. Degorgement et bouchage. In Le Champagne: De La Tradition à La Science, 2nd ed.; Lavoisier/Tec \& Doc: Paris, France, 2006; pp. 205-232.

15. Masneuf-Pomarede, I.; Bely, M.; Marullo, P.; Albertin, W. The genetics of non-conventional wine yeasts: Current knowledge and future challenges. Front. Microbiol. 2016, 6, 1563. [CrossRef] [PubMed]

16. Romani, C.; Lencioni, L.; Gobbi, M.; Mannazzu, I.; Ciani, M.; Domizio, P. Schizosaccharomyces japonicus: A polysaccharide-overproducing yeast to be used in winemaking. Fermentation 2018, 4, 14. [CrossRef]

17. Domizio, P.; Romani, C.; Lencioni, L.; Comitini, F.; Gobbi, M.; Mannazzu, I.; Ciani, M. Outlining a future for non-Saccharomyces yeasts: Selection of putative spoilage wine strains to be used in association with Saccharomyces cerevisiae for grape juice fermentation. Int. J. Food Microbiol. 2011, 147, 170-180. [CrossRef] [PubMed]

18. Jolly, N.P.; Varela, C.; Pretorius, I.S. Not your ordinary yeast: Non-Saccharomyces yeasts in wine production uncovered. FEMS Yeast Res. 2014, 14, 215-237. [CrossRef] [PubMed]

19. Comitini, F.; Gobbi, M.; Domizio, P.; Romani, C.; Lencioni, L.; Mannazzu, I.; Ciani, M. Selected non-Saccharomyces wine yeasts in controlled multistarter fermentations with Saccharomyces cerevisiae. Food Microbiol. 2011, 5, 873-882. [CrossRef] [PubMed]

20. Varela, C.; Siebert, T.; Cozzolino, D.; Rose, L.; Mclean, H.; Henschke, P.A. Discovering a chemical basis for differentiating wines made by fermentation with 'wild' indigenous and inoculated yeasts: Role of yeast volatile compounds. Aust. J. Grape Wine Res. 2009, 15, 238-248. [CrossRef]

21. García, M.; Esteve-Zarzoso, B.; Arroyo, T. Non-Saccharomyces Yeasts: Biotechnological Role for Wine Production. In Grape and Wine Biotechnology; Morata, A., Ed.; IntechOpen: London, UK, 2016; pp. $249-271$. [CrossRef]

22. Chasseriaud, L.; Coulon, J.; Marullo, P.; Albertin, W.; Bely, M. New oenological practice to promote non-Saccharomyces species of interest: Saturating grape juice with carbon dioxide. Appl. Microbiol. Biotechnol. 2018, 102, 3779-3791. [CrossRef] [PubMed]

23. Bagheri, B.; Bauer, F.F.; Setati, M.E. The impact of Saccharomyces cerevisiae on a wine yeast consortium in natural and inoculated fermentations. Front. Microbiol. 2017, 8, 1988. [CrossRef] [PubMed]

24. Padilla, B.; Gil, J.V.; Manzanares, P. Past and Future of Non-Saccharomyces Yeasts: From Spoilage Microorganisms to Biotechnological Tools for Improving Wine Aroma Complexity. Front. Microbiol. 2016, 7 , 411. [CrossRef] [PubMed]

25. Gschaedler, A. Contribution of non-conventional yeasts in alcoholic beverages. Curr. Opin. Food Sci. 2017, 13, 73-77. [CrossRef]

26. Lleixà, J.; Martín, V.; Portillo, M.D.; Carrau, F.; Beltran, G.; Mas, A. Comparison of Fermentation and Wines Produced by Inoculation of Hanseniaspora vineae and Saccharomyces cerevisiae. Front. Microbiol. 2016, 7, 338. [CrossRef]

27. Comitini, F.; Capece, A.; Ciani, M.; Romano, P. New insights on the use of wine yeasts. Curr. Opin. Food Sci. 2017, 13, 44-49. [CrossRef]

28. Petruzzi, L.; Capozzi, V.; Berbegal, C.; Corbo, M.R.; Bevilacqua, A.; Spano, G.; Sinigaglia, M. Microbial Resources and Enological Significance: Opportunities and Benefits. Front. Microbiol. 2017, 8, 995. [CrossRef] [PubMed]

29. Benito, S.; Hofmann, T.; Laier, M.; Lochbühler, B.; Schüttler, A.; Ebert, K.; Fritsch, S.; Röcker, J.; Rauhut, D. Effect on quality and composition of Riesling wines fermented by sequential inoculation with non-Saccharomyces and Saccharomyces cerevisiae. Eur. Food Res. Technol. 2015, 241, 707-717. [CrossRef]

30. Varela, B.; Borneman, A.R. Yeasts found in vineyards and wineries. Yeast 2017, 34, 111-128. [CrossRef] [PubMed]

31. Tristezza, M.; Tufariello, M.; Capozzi, V.; Spano, G.; Mita, G.; Grieco, F. The Oenological Potential of Hanseniaspora uvarum in Simultaneous and Sequential Co-fermentation with Saccharomyces cerevisiae for Industrial Wine Production. Front. Microbiol. 2016, 7, 670. [CrossRef] [PubMed] 
32. Hu, K.; Jin, G.J.; Xu, Y.H.; Tao, Y.S. Wine aroma response to different participation of selected Hanseniaspora uvarum in mixed fermentation with Saccharomyces cerevisiae. Food Res. Int. 2018, 108, 119-127. [CrossRef] [PubMed]

33. Medina, K.; Boido, E.; Fariña, L.; Gioia, O.; Gomez, M.E.; Barquet, M.; Gaggero, C.; Dellacassa, E.; Carrau, F. Increased flavour diversity of Chardonnay wines by spontaneous fermentation and co-fermentation with Hanseniaspora vineae. Food Chem. 2013, 141, 13-21. [CrossRef] [PubMed]

34. Loira, I.; Vejarano, R.; Banuelos, M.A.; Morata, A.; Tesfaye, W.; Uthurry, C.; Villa, A.; Cintora, I.; Suarez-Lepe, J.A. Influence of sequential fermentation with Torulaspora delbrueckii and Saccharomyces cerevisiae on wine quality. LWT-Food Sci. Technol. 2014, 59, 915-922. [CrossRef]

35. González-Royo, E.; Pascual, O.; Kontoudakis, N.; Esteruelas, M.; Esteve-Zarzoso, B.; Mas, A.; Canals, J.M.; Zamora, F. Oenological consequences of sequential inoculation with non-Saccharomyces yeasts (Torulaspora delbrueckii or Metschnikowia pulcherrima) and Saccharomyces cerevisiae in base wine for sparkling wine production. Eur. Food Res. Technol. 2015, 240, 999-1012. [CrossRef]

36. Medina-Trujillo, L.; González-Royo, E.; Sieczkowski, N.; Heras, J.; Fort, F.; Canals, J.M.; Zamora, F. Effect of sequential inoculation (Torulaspora delbrueckii/Saccharomyces cerevisiae) in the first fermentation on the foam properties of sparkling wine (Cava). Eur. Food Res. Technol. 2017, 243, 681-688. [CrossRef]

37. Belda, I.; Ruiz, J.; Beisert, B.; Navascués, E.; Marquina, D.; Calderon, F.; Rauhut, D.; Benito, S.; Santos, A. Influence of Torulaspora delbrueckii in varietal thiol (3-SH and 4-MSP) release in wine sequential fermentations. Int. J. Food Microbiol. 2017, 257, 183-191. [CrossRef] [PubMed]

38. Marcon, A.R.; Schwarz, L.V.; Dutra, S.V.; Moura, S.; Agostini, F.; Delamare, A.P.L.; Echeverrigaray, S. Contribution of a Brazilian Torulaspora delbrueckii isolate and a commercial Saccharomyces cerevisiae to the aroma profile and sensory characteristics of Moscato Branco wines. Aust. J. Grape Wine Res. 2018. [CrossRef]

39. Varela, C.; Barker, A.; Tran, T.; Borneman, A.; Curtin, C. Sensory profile and volatile aroma composition of reduced alcohol Merlot wines fermented with Metschnikowia pulcherrima and Saccharomyces uvarum. Int. J. Food Microbiol. 2017, 252, 1-9. [CrossRef] [PubMed]

40. Chen, K.; Escott, C.; Loira, I.; Del Fresno, J.M.; Morata, M.; Tesfaye, W.; Calderon, F.; Suarez-Lepe, J.A.; Han, S.; Benito, S. Use of non-Saccharomyces yeasts and oenological tannin in red winemaking: Influence on colour, aroma and sensorial properties of young wines. Food Microbiol. 2018, 69, 51-63. [CrossRef] [PubMed]

41. Benucci, I.; Cerreti, M.; Liburdi, K.; Nardi, T.; Vagnolic, P.; Ortiz-Julien, A.; Esti, M. Pre-fermentative cold maceration in presence of non-Saccharomyces strains: Evolution of chromatic characteristics of Sangiovese red wine elaborated by sequential inoculation. Food Res. Int. 2018, 107, 257-266. [CrossRef] [PubMed]

42. Englezos, V.; Torchio, F.; Cravero, F.; Marengo, F.; Giacosa, S.; Gerbi, V.; Rantsiou, K.; Rolle, L.; Cocolin, L. Aroma profile and composition of Barbera wines obtained by mixed fermentations of Starmerella bacillaris (synonym Candida zemplinina) and Saccharomyces cerevisiae. LWT-Food Sci. Technol. 2016, 73, 567-575. [CrossRef]

43. Morata, A.; Benito, S.; Loira, I.; Palomero, F.; Gonzalez, M.C.; Suarez-Lepe, J.A. Formation of pyranoanthocyanins by Schizosaccharomyces pombe during the fermentation of red must. Int. J. Food Microbiol. 2012, 159, 47-53. [CrossRef] [PubMed]

44. Benito, A.; Jeffares, D.; Palomero, F.; Calderón, F.; Bai, F.-Y.; Bähler, J.; Benito, S. Selected Schizosaccharomyces pombe Strains Have Characteristics That Are Beneficial for Winemaking. PLoS ONE 2016, 11, e0151102. [CrossRef] [PubMed]

45. Gobbi, M.; Comitini, F.; Domizio, P.; Romani, C.; Lencioni, L.; Mannazzu, I.; Ciani, M. Lachancea thermotolerans and Saccharomyces cerevisiae in simultaneous and sequential co-fermentation: A strategy to enhance acidity and improve the overall quality of wine. Food Microbiol. 2013, 33, 271-281. [CrossRef] [PubMed]

46. Lencioni, L.; Romani, C.; Gobbi, M.; Comitini, F.; Ciani, M.; Domizio, P. Controlled mixed fermentation at winery scale using Zygotorulaspora florentina and Saccharomyces cerevisiae. Int. J. Food Microbiol. 2016, 3, 36-44. [CrossRef] [PubMed]

47. Albertin, W.; Zimmer, A.; Miot-Sertier, C.; Bernard, M.; Coulon, J.; Moine, V.; Colonna-Ceccaldi, B.; Bely, M.; Marullo, P.; Masneuf-Pomarede, I. Combined effect of the Saccharomyces cerevisiae lag phase and the non-Saccharomyces consortium to enhance wine fruitiness and complexity. Appl. Microbiol. Biotechnol. 2017, 101, 7603-7620. [CrossRef] [PubMed] 
48. Garavaglia, J.; Schneider, R.D.; Mendes, S.D.; Welke, J.E.; Zini, C.A.; Caramao, E.B.; Valente, P. Evaluation of Zygosaccharomyces bailii BCV 08 as a co-starter in wine fermentation for the improvement of ethyl esters production. Microbiol. Res. 2015, 173, 59-65. [CrossRef] [PubMed]

49. Escribano, R.; González-Arenzana, L.; Portu, J.; Garijo, P.; López-Alfaro, I.; López, R.; Santamaría, P.; Gutiérrez, A.R. Wine aromatic compound production and fermentative behaviour within different non-Saccharomyces species and clones. J. Appl. Microbiol. 2018, 124, 1521-1531. [CrossRef] [PubMed]

50. Loira, I.; Morata, A.; Comuzzo, P.; Callejo, M.J.; González, C.; Calderón, F.; Suárez Lepe, J.A. Use of Schizosaccharomyces pombe and Torulaspora delbrueckii strains in mixed and sequential fermentations to improve red wine sensory quality. Food Res. Int. 2015, 76, 325-333. [CrossRef] [PubMed]

51. Canonico, L.; Comitini, F.; Ciani, M. Torulaspora delbrueckii for secondary fermentation in sparkling wine production. Food Microbiol. 2018, 74, 100-106. [CrossRef] [PubMed]

52. Ivit, N.N.; Loira, I.; Morata, A.; Benito, S.; Palomero, F.; Suarez-Lepe, J.A. Making natural sparkling wines with non-Saccharomyces yeasts. Eur. Food Res. Technol. 2018, 244, 925-935. [CrossRef]

53. Whitener, M.E.B.; Stanstrup, J.; Panzeri, V.; Carlin, S.; Divol, B.; Du Toit, M.; Vrhovsek, U. Untangling the wine metabolome by combining untargeted SPME-GCxGCTOF-MS and sensory analysis to profile Sauvignon blanc co-fermented with seven different yeasts. Metabolomics 2016, 12, 53. [CrossRef]

54. Balikci, E.K.; Tanguler, H.; Jolly, N.P.; Erten, H. Influence of Lachancea thermotolerans on cv. Emir wine fermentation. Yeast 2016, 33, 313-321. [CrossRef] [PubMed]

55. Martínez-Rodríguez, A.J.; Carrascosa, A.V.; Martin-Alvarez, P.J.; Moreno-Arribas, V.; Polo, M.C. Influence of the yeast strain on the changes of the amino acids, peptides and proteins during sparkling wine production by the traditional method. J. Ind. Microbiol. Biotechnol. 2002, 29, 314-322. [CrossRef] [PubMed]

56. Perpetuini, G.; Di Gianvito, P.; Arfelli, G.; Schirone, M.; Corsetti, A.; Tofalo, R.; Suzzi, G. Biodiversity of autolytic ability in flocculent Saccharomyces cerevisiae strains suitable for traditional sparkling wine fermentation. Yeast 2016, 33, 303-312. [CrossRef] [PubMed]

57. Di Gianvito, P.; Perpetuini, G.; Tittarelli, F.; Schirone, M.; Arfelli, G.; Piva, A.; Patrignani, F.; Lanciotti, R.; Olivastric, L.; Suzzi, G.; et al. Impact of Saccharomyces cerevisiae strains on traditional sparkling wines production. Food Res. Int. 2018, 109, 552-560. [CrossRef] [PubMed]

58. Borrull, A.; Poblet, M.; Rozes, N. New insights into the capacity of commercial wine yeasts to grow on sparkling wine media. Factor screening for improving wine yeast selection. Food Microbiol. 2015, 48, 41-48. [CrossRef] [PubMed]

59. Penacho, V.; Valero, E.; Gonzalez, R. Transcription profiling of sparkling wine second fermentation. Int. J. Food Microbiol. 2012, 153, 176-182. [CrossRef] [PubMed]

60. Garofalo, C.; Arena, M.P.; Laddomada, B.; Cappello, M.S.; Bleve, G.; Grieco, F.; Beneduce, L.; Berbegal, C.; Spano, G.; Capozzi, V. Starter Cultures for Sparkling Wine. Fermentation 2016, 2, 21. [CrossRef]

61. Suárez Lepe, J.A.; Iñigo Leal, B. Vinificaciones especiales desde el punto de vista microbiológico. In Microbiología Enológica, Fundamentos de Vinificación, 3rd ed.; Ediciones Mundi-Prensa: Madrid, Spain, 2004; pp. 607-673.

62. Jackson, R.S. Fermentation. In Wine Science: In Principles and Applications, 4th ed.; Academic Press/Elsevier: Hoboken, NJ, USA, 2014; pp. 427-534.

63. Martínez-Rodríguez, A.J.; Polo, M.C. Effect of the addition of bentonite to the tirage solution on the nitrogen composition and sensory quality of sparkling wines. Food Chem. 2003, 81, 383-388. [CrossRef]

64. Alexandre, H.; Guilloux-Benatier, M. Yeast autolysis in sparkling wine-A review. Aust. J. Grape Wine Res. 2006, 12, 119-127. [CrossRef]

65. Moreno-Arribas, M.V.; Polo, M.C.; Pozo-Bayón, M.A. Peptides. In Wine Chemistry and Biochemistry; Moreno-Arribas, M.V., Polo, M.C., Eds.; Springer Science Business Media LLC: Berlin, Germany, 2009; pp. 191-209.

66. Martí-Raga, M.; Sancho, M.; Guillamon, J.M.; Mas, A.; Beltran, G. The effect of nitrogen addition on the fermentative performance during sparkling wine production. Food Res. Int. 2015, 67, 126-135. [CrossRef]

67. Gobert, A.; Tourdot-Maréchal, T.; Morge, C.; Sparrow, C.; Liu, Y.; Quintanilla-Casas, B.; Vichi, S.; Alexandre, H. Non-Saccharomyces yeasts nitrogen source preferences: Impact on sequential fermentation and wine volatile compounds profile. Front. Microbiol. 2017, 8, 2175. [CrossRef] [PubMed] 
68. Moreno-Arribas, V.; Pueyo, E.; Polo, M.C.; Martin-Alvarez, P.J. Changes in the Amino Acid Composition of the Different Nitrogenous Fractions during the Aging of Wine with Yeasts. J. Agric. Food Chem. 1998, 46, 4042-4051. [CrossRef]

69. Charpentier, C.; Feuillat, M. Yeast autolysis. In Wine Microbiology and Biotechnology; Fleet, G., Ed.; Harwood Academic Publishers: London, UK, 1993; pp. 225-242.

70. Borrull, A.; Lopez-Martínez, G.; Miro-Abella, E.; Salvado, Z.; Poblet, M.; Cordero-Otero, R.; Rozes, N. New insights into the physiological state of Saccharomyces cerevisiae during ethanol acclimation for producing sparkling wines. Food Microbiol. 2016, 54, 20-29. [CrossRef]

71. Leroy, M.J.; Charpentier, M.; Duteurtre, B.; Feuillat, M.; Charpentier, C. Yeast Autolysis during Champagne Aging. Am. J. Enol. Vitic. 1990, 41, 21-28.

72. Martí-Raga, M.; Marullo, P.; Beltran, G.; Mas, A. Nitrogen modulation of yeast fitness and viability during sparkling wine production. Food Microbiol. 2016, 54, 106-114. [CrossRef]

73. Feuillat, M.; Charpentier, C. Autolysis of yeasts in Champagne. Am. J. Enol. Vitic. 1982, 33, 6-13.

74. Ribéreau-Gayon, P.; Glories, Y.; Maujean, A.; Dubourdieu, D. Nitrogen Compounds. In Handbook of Enology the Chemistry of Wine Stabilization and Treatments, 2nd ed.; John Wiley and Sons Ltd.: Hoboken, NJ, USA, 2006; Volume 2, pp. 109-140.

75. Lambrechts, M.G.; Pretorius, I.S. Yeast and its Importance to Wine Aroma-A Review. S. Afr. J. Enol. Vitic. 2000, 21, 97-129.

76. Bozdogan, A.; Canbas, A. Influence of yeast strain, immobilisation and ageing time on the changes of free amino acids and amino acids in peptides in bottle-fermented sparkling wines obtained from Vitis vinifera $\mathrm{cv}$. Emir. Int. J. Food Sci. Technol. 2011, 46, 1113-1121. [CrossRef]

77. Bozdogan, A.; Canbas, A. The effect of yeast strain, immobilisation, and ageing time on the amount of free amino acids and amino acids in peptides of sparkling wines obtained from cv. Dimrit grapes. S. Afr. J. Enol. Vitic. 2012, 33, 257-263. [CrossRef]

78. Puig-Deu, M.; Lopez-Tamames, E.; Buxaderas, S.; Torre-Boronat, M.C. Quality of base and sparkling wines as influenced by the type of fining agent added pre-fermentation. Food Chem. 1999, 66, 35-42. [CrossRef]

79. Lleixà, J.; Manzano, M.; Mas, A.; Portillo, M.C. Saccharomyces and non-Saccharomyces competition during microvinification under different sugar and nitrogen conditions. Front. Microbiol. 2016, 7, 1959. [CrossRef] [PubMed]

80. Palomero, F.; Morata, A.; Benito, S.; Calderón, F.; Suárez-Lepe, J.A. New genera of yeasts for over-lees aging of red wine. Food Chem. 2009, 112, 432-441. [CrossRef]

81. Marcobal, A.; Martin-Alvarez, P.J.; Polo, M.C.; Munoz, R.; Moreno-Arribas, M.V. Formation of Biogenic Amines throughout the Industrial Manufacture of Red Wine. J. Food Prot. 2006, 69, 397-404. [CrossRef] [PubMed]

82. Anli, R.E.; Bayram, M. Biogenic Amines in Wines. Food Rev. Int. 2008, 25, 86-102. [CrossRef]

83. Ke, R.; Weic, Z.; Bogdald, C.; Göktaşe, R.K.; Xiaoa, R. Profiling wines in China for the biogenic amines: A nationwide survey and pharmacokinetic fate modelling. Food Chem. 2018, 250, 268-275. [CrossRef] [PubMed]

84. Martuscelli, M.; Arfelli, G.; Manetta, A.C.; Suzzi, G. Biogenic amines content as a measure of the quality of wines of Abruzzo (Italy). Food Chem. 2013, 140, 590-597. [CrossRef] [PubMed]

85. Lorenzo, C.; Bordiga, M.; Pérez-Álvarez, E.P.; Travaglia, F.; Arlorio, M.; Salinasa, M.R.; Coïsson, J.D.; Garde-Cerdán, T. The impacts of temperature, alcoholic degree and amino acids content on biogenic amines and their precursor amino acids content in red wine. Food Res. Int. 2017, 99, 328-335. [CrossRef] [PubMed]

86. Marques, A.P.; Leitao, M.C.; San Romao, M.V. Biogenic amines in wines: Influence of oenological factor. Food Chem. 2008, 107, 853-860. [CrossRef]

87. Costantini, A.; Vaudano, E.; Del Prete, V.; Danei, M.; Garcia-Moruna, E. Biogenic Amine Production by Contaminating Bacteria Found in Starter Preparations Used in Winemaking. J. Agric. Food Chem. 2009, 57, 10664-10669. [CrossRef] [PubMed]

88. Garcia-Ruiz, A.; Gonzalez-Rompinelli, E.M.; Bartollome, B.; Moreno-Arribas, M.V. Potential of wine-associated lactic acid bacteria to degrade biogenic amines. Int. J. Food Microbiol. 2011, 148, 115-120. [CrossRef] [PubMed]

89. Granchi, L.; Romano, P.; Mangani, S.; Guerrini, S.; Vincenzini, M. Production of biogenic amines by wine microorganisms. Bull. OIV 2005, 78, 595-610. 
90. Caruso, M.; Fiore, C.; Contursi, M.; Salzano, G.; Paparella, A.; Romano, P. Formation of biogenic amines as criteria for the selection of wine yeasts. World J. Microbiol. Biotechnol. 2002, 18, 159-163. [CrossRef]

91. Lehtonen, P. Determination of amines and amino acids in wine: A review. Am. J. Enol. Vitic. 1996, 47, 127-133.

92. Sanlibaba, P.; Uymaz, B. Biogenic Amine Formation in Fermented Foods: Cheese and Wine. Eur. Int. J. Sci. Technol. 2015, 4, 81-92.

93. Wantke, F.; Moritz, K.; Sesztak-Greinecker, G.; Gotz, M.; Hemmer, W. Histamine Content in Red and Sparkling Wine and Relationship with Wine Quality. J. Allergy Clin. Immunol. 2008, 121, 194. [CrossRef]

94. Konakovsky, V.; Focke, M.; Hoffmann-Sommergruber, K.; Schmid, R.; Scheiner, O.; Moser, P.; Hemmer, W.; Jarisch, R. Levels of Histamine and other Biogenic Amines in Red Wines and Sparkling Wines. J. Allergy Clin. Immunol. 2011, 127, AB242. [CrossRef]

95. Ancin-Azpilicueta, C.; Gonzalez-Marco, A.; Jimenez-Moreno, N. Current knowledge about the presence of amines in wine. Crit. Rev. Food Sci. Nutr. 2008, 48, 257-275. [CrossRef] [PubMed]

96. Pozo-Bayón, M.A.; Monagas, M.; Bartolome, B.; Moreno-Arribas, V. Wine futures related to safety and consumer health: An integrated perspective. Crit. Rev. Food Sci. Nutr. 2012, 52, 31-54. [CrossRef] [PubMed]

97. Rapp, A.; Mandery, H. Wine aroma. Experentia 1986, 42, 873-884. [CrossRef]

98. Azzolini, M.; Fedrizzi, B.; Tosi, E.; Finato, F.; Vagnoli, P.; Scrinzi, C.; Zapparoli, G. Effects of Torulaspora delbrueckii and Saccharomyces cerevisiae mixed cultures on fermentation and aroma of Amarone wine. Eur. Food Res. Technol. 2012, 235, 303-313. [CrossRef]

99. Varela, C. The impact of non-Saccharomyces yeasts in the production of alcoholic beverages. Appl. Microbiol. Biotechnol. 2016, 100, 9861-9874. [CrossRef] [PubMed]

100. Kemp, B.; Hogan, C.; Xu, S.; Dowling, L.; Inglis, D. The impact of wine style and sugar addition in liqueur d'expedition (dosage) solutions on traditional method sparkling wine composition. Beverages 2017, 3, 7. [CrossRef]

101. Gallardo-Chacon, J.; Vichi, S.; López-Tamames, E.; Buxaderas, S. Changes in the Sorption of Diverse Volatiles by Saccharomyces cerevisiae Lees during Sparkling Wine Aging. J. Agric. Food Chem. 2010, 58, 12426-12430. [CrossRef] [PubMed]

102. Mamede, M.E.O.; Cardello, H.M.A.B.; Pastore, G.M. Evaluation of an aroma similar to that of sparkling wine: Sensory and gas chromatography analyses of fermented grape musts. Food Chem. 2005, 89, 63-68. [CrossRef]

103. Kemp, B.; Condé, B.; Jégou, S.; Howell, K.; Vasserot, Y.; Marchal, R. Chemical Compounds and Mechanisms involved in the Formation and Stabilization of Foam in Sparkling Wines. Crit. Rev. Food Sci. Nutr. 2018. [CrossRef] [PubMed]

104. Waters, E.J.; Wallace, W.; Williams, P.J. Identification of heat unstable wine proteins and their resistance to peptidases. J. Agric. Food Chem. 1992, 40, 1514-1519. [CrossRef]

105. Goncalves, F.; Heyraud, A.; de Pinho, M.N.; Rinaudo, M. Characterisation of white wine mannoproteins. J. Agric. Food Chem. 2002, 50, 6097-6101. [CrossRef] [PubMed]

106. Fleet, G.H. Cell wall. In The Yeasts: Yeast Organelles; Rose, A.H., Harrison, J.S., Eds.; Academic Press: London, UK, 1991; Volume 4, pp. 199-277.

107. Klis, F.M.; Boorsma, A.; De Grot, P.W.J. Cell wall construction in Saccharomyces cerevisiae. Yeast 2006, 23, 185-202. [CrossRef] [PubMed]

108. Giovani, G.; Rosi, I.; Bertuccioli, M. Quantification and characterization of cell wall polysaccharides released by non-Saccharomyces yeast during alcoholic fermentation. Int. J. Food Microbiol. 2012, 160, 113-118. [CrossRef] [PubMed]

109. Domizio, P.; Liu, Y.; Bission, L.F.; Barile, D. Use of non-Saccharomyces wine yeasts as novel sources of mannoproteins in wine. Food Microbiol. 2014, 43, 5-15. [CrossRef] [PubMed]

110. Benito, S.; Palomero, F.; Morata, A.; Calderón, F.; Suárez-Lepe, J.A. New applications for Schizosaccharomyces pombe in the alcoholic fermentation of red wines. Int. Food J. Sci. Technol. 2012, 47, 2101-2108. [CrossRef]

111. Bertuccioli, M.; Ferrari, S. Laboratory experience on the influence of yeast in mouthfeel. In Proceedings of the Les Entretiens Scientifiques De Lallemand, Montreal, QC, Canada, 25 September 1999.

112. Polo, M.C.; Gonzalez de Llano, M.D.; Ramos, M. Derivatization and liquid chromatographic separation of peptides. In Food Analysis by HPLC; Nollet, M.L., Ed.; Dekker: New York, NY, USA, 1992; pp. 117-140. 
113. Contreras, A.; Hidalgo, C.; Schmidt, S.; Henshke, P.A.; Curtin, C.; Varela, C. The application of non-Saccharomyces yeast in fermentations with limited aeration as a strategy for the production of wine with reduced alcohol content. Int. J. Food Microbiol. 2015, 105, 7-15. [CrossRef] [PubMed]

114. Alonso-del-Rio, J.; Lairón-Peris, M.; Barrio, E.; Querol, A. Effect on the prevalence of Saccharomyces non cerevisiae species against $S$. cerevisiae wine strain on wine fermentation: Competition, physiological fitness, and influence in final wine composition. Front. Microbiol. 2017, 8, 150. [CrossRef]

115. Pérez-Torrado, R.; Barrio, E.; Querol, A. Alternative yeasts for winemaking: Saccharomyces non-cerevisiae and its hybrids. Crit. Rev. Food Sci. Nutr. 2018, 58, 1780-1790. [CrossRef] [PubMed]

116. Morata, A.; Loira, I.; Tesfaye, W.; Bañuelos, M.A.; González, C.; Suárez-Lepé, J.A. Lachancea thermotolerans applications in wine technology. Fermentation 2018, 4, 53. [CrossRef]

117. Kapsopoulou, K.; Kapaklis, A.; Spyropoulos, H. Growth and fermentation characteristics of a strain of the wine yeast Kluyveromyces thermotolerans isolated in Greece. World J. Microbiol. Biotechnol. 2005, 21, 1599-1602. [CrossRef]

118. Balmaseda, A.; Bordona, A.; Reguant, C.; Bauttista-Gallego, J. Non-Saccharomyces in wine: Effect upon Oenococcus oeni and malolactic fermentation. Front. Microbiol. 2018, 9, 534. [CrossRef] [PubMed]

119. Belda, I.; Navascués, E.; Marquina, D.; Santos, A.; Calderon, F.; Benito, S. Dynamic analysis of physiological properties of Torulaspora delbrueckii in wine fermentations and its incidence on wine quality. Appl. Microbiol. Biotechnol. 2015, 99, 1911-1922. [CrossRef] [PubMed]

120. Puertas, B.; Jiménez, M.J.; Cantos-Villar, E.; Cantoral, J.M.; Rodriguez, M.E. Use of Torulaspora delbuckii and Saccharomyces cerevisiae in semi-industrial inoculation to improve quality of Palomino and Chardonnay wines in warm countries. J. Appl. Microbiol. 2017, 122, 733-746. [CrossRef] [PubMed]

121. Benito, S. The impact of Torulaspora delbrueckii yeast in winemaking. Appl. Microbiol. Biotechnol. 2018, 102, 3081-3094. [CrossRef] [PubMed]

122. Maicas, S.; Ferrer, S.; Pardo, I. NAD(P)H regeneration is the key for heterolactic fermentation of hexoses in Oenococcus oeni. Microbiology 2002, 148, 325-332. [CrossRef] [PubMed]

123. Benito, S.; Palomero, P.; Calderón, F.; Palmero, D.; Suárez-Lepé, J.A. Selection of appropriate Schizosaccharomyces strains for winemaking. Food Microbiol. 2014, 42, 218-224. [CrossRef] [PubMed]

124. Zhang, X.K.; Lan, Y.B.; Zhu, B.Q.; Xiang, X.F.; Duana, C.Q.; Shia, Y. Changes in monosaccharides, organic acids and amino acids during Cabernet Sauvignon wine ageing based on a simultaneous analysis using gas chromatography-mass spectrometry. J. Food Sci. Agric. 2017, 98, 104-112. [CrossRef] [PubMed]

125. Vannier, A.; Brun, O.X.; Feinberg, M.H. Application of sensory analysis to champagne wine characterisation and discrimination. Food Qual. Prefer. 1999, 10, 101-107. [CrossRef]

126. Buxaderas, S.; López-Tamames, E. Managing the quality of sparkling wine. In Managing Wine Quality, Viticulture and Wine Quality; Reynolds, A., Ed.; Woodhead Food Series: Sawston, UK, 2010; Volume 2, pp. 553-588.

127. Martínez-Rodríguez, A.; Carrascosa, A.V.; Barcenilla, J.M.; Pozo-Bayón, M.A.; Polo, M.C. Autolytic capacity and foam analysis as additional criteria for the selection of yeast strains for sparkling wine production. Food Microbiol. 2001, 18, 183-191. [CrossRef]

128. Hidalgo, P.; Pueyo, E.; Pozo-Bayón, M.A.; Martínez-Rodríguez, A.J.; Martinez-Alvarez, P.; Polo, M.C. Sensory and Analytical Study of Rosé Sparkling Wines Manufactured by Second Fermentation in the Bottle. J. Agric. Food Chem. 2004, 52, 6640-6645. [CrossRef] [PubMed]

129. McMahon, K.M.; Diako, C.; Aplin, J.; Mattinson, D.S.; Culver, C.; Rossa, C.F. Trained and consumer panel evaluation of sparkling wines sweetened to brut or demi sec residual sugar levels with three different sugars. Food Res. Int. 2017, 99, 173-185. [CrossRef] [PubMed]

130. López de Lerma, N.; Peinado, R.A.; Puig-Pujol, A.; Mauricioc, J.C.; Moreno, J.; García-Martínez, T. Influence of two yeast strains in free, bioimmobilized or immobilized with alginate forms on the aromatic profile of long aged sparkling wines. Food Chem. 2018, 250, 22-29. [CrossRef] [PubMed]

131. Liger-Belair, G.; Polidoric, G.; Zéninaria, V. Unraveling the evolving nature of gaseous and dissolved carbon dioxide in champagne wines: A state-of-the-art review, from the bottle to the tasting glass. Anal. Chim. Acta 2012, 732, 1-15. [CrossRef] [PubMed]

132. Obiols, J.M.; De la Presa-Owens, C.; Buxaderas, S.; Bori, J.L.; De la Torre-Boronat, C. Protocolo de evaluación de la formación de la efervescencia y espuma en un vino espumoso. ACE Revista de Enología 1998, 15, 3-15. 
133. Gallart, M.; Tomás, X.; Suberiola, G.; López-Tamames, E.; Buxaderas, S. Relationship between foam parameters obtained by the gas-sparging method and sensory evaluation of sparkling wines. J. Sci. Food Agric. 2004, 84, 127-133. [CrossRef]

134. Torrens, J.; Riu-Aumatell, M.; Vichi, S.; López-Tamames, E.; Buxaderas, S. Assessment of Volatile and Sensory Profiles between Base and Sparkling Wines. J. Agric. Food Chem. 2010, 58, 2455-2461. [CrossRef] [PubMed]

135. Duteurtre, B. L'organisation champenoise. In Le Champagne: De la Tradition à la Science, 2nd ed.; Lavoisier/Tec \& Doc: Paris, France, 2006; pp. 19-32.

136. Jolly, N.P.; Augustyn, O.P.H.; Pretorius, I.S. The Role and Use of Non-Saccharomyces Yeasts in Wine Production. S. Afr. J. Enol. Vitic. 2006, 27, 15-39. [CrossRef]

137. Arroyo-Lopez, F.N.; Perez-Torrado, R.; Querol, A.; Barrio, E. Modulation of the glycerol and ethanol syntheses in the yeast Saccharomyces kudriavzevii differs from that exhibited by Saccharomyces cerevisiae and their hybrid. Food Microbiol. 2010, 27, 628-637. [CrossRef] [PubMed]

138. Soden, A.; Francis, I.L.; Oakey, H.; Henschke, P.A. Effects of co-fermentation with Candida stellata and Saccharomyces cerevisiae on the aroma and composition of Chardonnay wine. Aust. J. Grape Wine Res. 2000, 6, 21-30. [CrossRef]

139. Domizio, P.; Liu, Y.; Bisson, L.F.; Barile, D. Cell wall polysaccharides released during the alcoholic fermentation by Schizosaccharomyces pombe and S. japonicus: Quantification and characterization. Food Microbiol. 2017, 61, 136-149. [CrossRef] [PubMed]

140. Bely, M.; Stoeckle, P.; Masneuf-Pomarede, I.; Dubourdieu, D. Impact of mixed Torulaspora delbrueckii Saccharomyces cerevisiae culture on high-sugar fermentation. Int. J. Food Microbiol. 2008, 122, 312-320. [CrossRef] [PubMed]

141. Renault, P.; Miot-Sertier, C.; Marullo, P.; Hernandez-Orte, P.; Lagarrigue, L.; Lonvaud- Funel, A.; Bely, M. Genetic characterization and phenotypic variability in Torulaspora delbrueckii species: Potential applications in the wine industry. Int. J. Food Microbiol. 2009, 134, 201-210. [CrossRef] [PubMed]

(C) 2018 by the authors. Licensee MDPI, Basel, Switzerland. This article is an open access article distributed under the terms and conditions of the Creative Commons Attribution (CC BY) license (http:// creativecommons.org/licenses/by/4.0/). 